\title{
Eğitim Kurumlarında Stratejik Risklerin Tespiti
}

DOI: $10.26466 /$ opus.814252

*

\author{
Ömer Faruk Ak ${ }^{*}$ - Sevilay Şahin ** \\ ${ }^{*}$ Dr. Niğde Valiliği, Niğgde/Türkiye \\ E-Posta: omerfaruk.ak@hotmail.com \\ ORCID: $\underline{0000-0002-4329-9327}$ \\ **Prof. Dr, Gaziantep Üniversitesi, Eğitim Fakültesi, Gaziantep/Türkiye \\ E-Posta: ssahin@gantep.edu.tr \\ ORCID: $\underline{0000-0002-7140-821 X}$
}

\section{Öz}

Kurumun stratejik hedeflerinin gerçekleşmesini engelleyebilecek tehditler ve olumsuzluklar şeklinde tanımlanan risklerin doğru tespit edilmesi kurumun daha etkili yönetilmesi açısından önemlidir. Zira okullarda yapılan stratejik planlama kapsaminda belirlenen stratejilerin dayanak noktaları ne kadar gerçekçi ve güvenilir ise okulun hedeflerine ulaşma oranı da o derece yüksek olacaktır. Bu doğrultuda yürütülen çalışmada, ortaöğretim okullarının meydana gelebilecek önemli risklerin iç kontrol modeline göre tespit edilerek değerlendirilmesi amaçlanmaktadır. Bu sayede risklerini doğru tespit eden ve değerlendiren okullar belirledikleri hedeflere daha kolay ulaşabilecektir. Nicel yöntemlerle yürütülen araştırmanın örneklemi Niğde ilindeki liselerde görev yapan okul yöneticisi ve öğretmenlerden oluşmaktadır. Araştırmada verileri toplamak için Okul İç Risklerini Değerlendirme Ölçeği kullanılmıştır. Analiz aşamasında ölçekteki her risk için risk puanı, aritmetik ortalama ve standart sapma değerleri hesaplanmıştır. Araştırma sonucunda elde edilen bulgulara göre öğretmenlerin mesleki gelişim ve etik alanında ve okullarm güvenlik ve sağlık alaninda meydana gelebilecek riskler diğer alanlara oranla daha riskli değerlendirilmiştir. Katılımcılar tarafindan güvenlik ve sağlık alanındaki risklerin oluşma olasılığı görece olarak düşük görülse de oluştuğu takdirde etkisinin yüksek olacă̆ı sonucuna ulaşılmıştir.

Anahtar Kelimeler: Risk, okul yönetimi, iç kontrol modeli, risk yönetimi, stratejik plan 


\title{
Determination of Strategic Risks in Educational Institutions
}

\begin{abstract}
It is important for the institution to be managed more effectively by identifying and controlling all kinds of risks defined as threats and negativities that may prevent the realization of the strategic goals of the institution. Because the more realistic and reliable the mainstays of the strategies determined within the framework of strategic planning in schools, the higher the rate of achievement of the school's goals will be. In this study, it is aimed to determine and evaluate the important risks that may occur in secondary schools according to the internal control model. In this way, schools that correctly identify and evaluate their risks will be able to reach their goals more easily. The sample of the study conducted with quantitative methods consists of school administrators and teachers working in high schools in Niğde. The study used the school Internal Risk Assessment Scale to collect data. Risk score, arithmetic mean and standard deviation values were calculated for each risk in the analysis phase. According to the findings obtained as a result of the research, the risks that may occur in the field of professional development and ethics of teachers and in the field of safety and health of schools were considered more risky than in other areas. Although the probability of occurrence of risks in the field of safety and health is relatively low by the participants, it has been concluded that if they occur, their impact will be high.
\end{abstract}

Keywords: Risk, school management, internal control model, risk management, strategic plan 


\section{Giriş}

Sosyal, siyasal ve iktisadi yaşamda ortaya çıkan ani gelişmeler ve belirsizlikler, kamu ve özel sektördeki kurum veya kuruluşların faaliyetlerini çok değişken bir zeminde sürdürme gerekliliğini doğurmuştur. Bu durum, geleceğin planlanması ve bu süreçte kaynakların verimli bir şekilde kullanılabilmesi için yönetimin temel işlevlerinden biri olan planlamanın çok daha etkin bir biçimde kullanılmasını da beraberinde getirmiştir. Kamu ya da özel kesimde faaliyetini sürdüren bir kurum, hangi yöne doğru gittiğini belirleyebilmek için öncelikle, tam olarak nerede olduğunu, sonrasında ise nereye gitmek istediğini ve ulaşmak istediği yere nasıl erişebileceğini bilmek isteyecektir. Bu bağlamda, yürütülecek faaliyetlerin sekteye uğramaması ve hedeflere ulaşmak için yapılan planlamanın çok mantıklı ve zekice bir hazırlık olduğu söylenebilir (Kriemadis ve Terzoudis, 2007, s.12).

Eğitim kurumları, hem vatandaşların temel hakları olan eğitim hakkını kullanarak gerçek hayatın zorluklarına karşı hazırlanmaları için hem de bu bireylerin ülkenin gelişmesine katkı sağlayacak bilgi ve becerilerle donanmış biçimde yetiştirilebilmesi amacıyla kurulan örgütsel yapılardır. Bu kurumlarda meydana gelen aksamalar kişilerin ciddi hak kayıplarına yol açabilmekte ve aynı zamanda ülkenin geleceği içinde telafisi güç zararlar oluşturabilmektedir. $\mathrm{Bu}$ nedenle okulların işleyişini tesadüflere bağlı olarak yürütme lüksü bulunmamakta, tüm faaliyetlerin yapılacak olan planlamaya göre sürdürülmesi gerekmektedir. Bu doğrultuda okullarda hedeflere doğru adımlarla ilerlemek ve eğitim alan öğrencilerin hak kayıplarına uğramaması için yaklaşık on yıldır belirli dönemlerde geleceğe yönelik stratejik planlamalar yapılmaktadır.

Dooris, Kelley ve Trainer'e (2004, s.9) göre planlama, geleceğin değerlendirilmesi, amaçların belirlenmesi ve bu amaçları elde edecek yolların tasarlanmasıdır. Yapılan planlama kişiye ya da kuruma fayda getirecek ve ona daha iyi koşullar sağlayacak beceriler ile ilgilidir. Bir organizasyonda hangi işin neden yapıldığı sorgulanarak genel stratejik amaç ve hedeflerin belirlenmesinde disiplinli bir çalışma olması nedeniyle stratejik planlamanın kurumlar ve işletmeler için çok fazla sayıda faydası bulunmaktadır (Steiss, 2003: 3; Gençkaya ve Gündoğdu, 2017).

Akyüz'e (2010, s.124) göre stratejik planlama, uzun vadeli bir planlama olması nedeniyle eğitim kurumları için diğer planlama türlerine göre daha 
uygun bir planlama türüdür. Işık ve Aypay (2004, s.351) ise eğitim kurumlarının diğer kurumlar ya da özel işletmeler gibi yönetilmedikleri için eğitim kurumlarında hazırlanan stratejik planların, diğer alanlarda yapılan stratejik planlamalara göre farklılıklar taşıdığını belirtmektedirler. Bir kurumun bulunduğu konum ile varmak istediği konum arasındaki yolu gösteren stratejik planlama da katılım, iletişim, farklı değerlerin ve çıkarların barındırılmaS1, analitik incelemelere göre kararların alınması ve hesap verebilirliğin kolaylaştırılması gibi ilkeler benimsenmektedir. Benimsenen bu ilkeler okulların etkili yönetilmesi açısından önemli ilkelerdir. Çünkü başarılı bir stratejik planlama okulu maruz kalabileceği tehdit, belirsizlik ve risklere karşı korurken aynı zamanda okulun tüm paydaşlarını da işin içine katarak ortak akılla kararlar alınmasına olanak sağlayabilmelidir.

Teorik olarak çok sayıda faydası olması beklenen stratejik planların okullarda uygulanmasında bir takım sorunlar yaşandığı bilinmektedir. Yürürlükte olan mevzuata göre bütün okullarda hazırlanması ve uygulanması zorunlu tutulan stratejik planlamanın, gerek işlevsel olarak hazırlandığını, gerekse uygulama süreçlerinin amaca uygun olarak gerçekleştirildiğini söylemek güçtür. Bu konuda yapılan birçok araştırma da; stratejik planların usulüne uygun şekilde yapılmadığı, okulların mevcut durumları ile stratejik planlamalarının uyuşmadığını, stratejik plan hazırlık süreçlerinin sadece kâğıt üzerinde kaldığı ve stratejik plan uygulama aşamalarının öngörülen amaçlara tam ve doğru şekilde hizmet etmediği sonuçları ortaya çıkmıştır (Işık ve Aypay, 2004; Şahin ve Aslan, 2008; Altınkurt, 2010; Kocatepe, 2010; Küçüker, 2010; Yelken, Kılıç ve Üredi, 2010; Balcı, Çanakçı ve Tan, 2012; Memduhoğlu ve Uçar, 2012; Balkar ve Ekici, 2015; Arslan ve Küçüker, 2016).

Okullarda hazırlanan stratejik planlamalarla ilgili yürütülen araştırmalarda belirtilen bu sorunlar, okulların yapısı nedeniyle sadece okul çalışanlarını ilgilendirmeyip, toplumun tüm kesimlerini etkileyecek sonuçlar doğurabileceği göz önünde bulundurulmalı ve öğrenciler başta olmak üzere okulun tüm paydaşları için faydalı, gerçekçi, uygulanabilir ve doğru stratejiler belirlenmelidir.

Bu noktada okullardaki temel eksikliğin stratejik planlarında belirledikleri hedeflere nasıl ulaşılması gerektiğiyle ilgili bir yönetim modelinin bulunmaması olduğu söylenebilir. Çünkü Tunç'a (2014, s.125) göre hazırlanan stratejik planlamanın başarısı, kurumun maruz kalabileceği belirsizlik, tehdit ve risklere karşı kurumu koruyabilmesi ve aynı zamanda fırsatlardan da 
yararlandırarak doğru bir şekilde konumlandırabilmesi ile ölçülebilir. Bu bağlamda iç ve diş çevrede neler olduğunun doğru tespit edilerek gerektiğinde örgütün yeniden şekillendirilmesi gerekmektedir. Gerçekleştirilecek eylemlerle ilgili doğru kararların alınması süreci, eksiklik ve hatalar daha ortaya çımadan önlenerek bir işin ilk defasında doğru yapılmasıyla yakın ilişkisi bulunmaktadır. Zira bir kurum gerçekleşme ihtimali bulunan farklı durumlara ne kadar hazırlıklı ise bu durumlar karşısında strateji üretmesi de o kadar kolay olacaktır. Kurumlar tarafından seçilen stratejilerin, sonuçları itibariyle riskli olabilecek seçimler olduğunu belirten Tunç'a (2014) göre stratejik planlama esasen belirsizlik ve riskleri yönetebilmek için kullanılan yönetsel araçlardır. Stratejik planların başarılı bir şekilde uygulanabilmesi, gelecekle ilgili belirsizliklerin gerçekleşme durumları hakkında doğru tespitler yapılarak bunların yönetilmesi ile doğrudan ilişkilidir.

Yereli'ye (2007, s.17) göre ise kurumların sürekli, kaliteli ve güvenilir hizmetler verebilmesi için amaçlara yönelik stratejik hedefler belirlemesi ve bu hedeflere göre faaliyet süreçlerini iyi yönetmesi zorunlu hale gelmiştir. Eğer bir organizasyon herhangi bir alanda faaliyet gösteriyorsa, bu faaliyetleri kapsamında doğal olarak olumsuz durumların ortaya çıkma olasılığ var olacaktır. Risk olarak tanımlanan bu olasılıkların sıfıra indirilmesi söz konusu olmadığından, kurumda oluşturulacak etkin bir risk yönetimi sayesinde, riskler azaltılmaya ve ortaya çıabilecek olumsuz etkileri asgari düzeye indirilmeye çalışılmalıdır. Sözlükte; "zarara uğrama tehlikesi" (TDK, 2019) şeklinde tanımlanan riskin mevzuattaki tanımı; "kamu idarelerinin kuruluş amaçlar ile stratejik hedeflerine ulaşmasına ve görevlerinin ifasına engel olabilecek veya beklenmeyen zararlara yol açabilecek durum ya da olaylardır" (Maliye Bakanlığı, 2006) şeklindedir.

Risk, kurumların faaliyetlerinin ve işlemlerinin yapısında olan bir olgudur. Bu nedenle büyüklüklerine, yapılarına, doğalarına ve sektörlerine göre iç veya dış kaynaklardan gelebilecek büyüklü küçüklü çok farklı risklerle karşı karşıya kalan kurumlar, faaliyet gösterdikleri alanlara uygun risk türlerine odaklanmaları gerekir. Bu aşamada kurumda var olan kapasitenin en verimli şekilde kullanılabilmesi için maruz kalınabilecek risklerin ne şekilde tespit edileceği ve bu risklerin nasıl yönetileceği ile ilgili karar verilmesi gerekmektedir. Alptürk'e (2008, s.238) göre bir kurumda mevcut riskler yönetilirken iki farklı yöntem izlenebilir. Bunlardan birincisi mevcut riskleri tek tek ele alarak geleneksel bakış açısıyla yönetmektir. İkinci yöntem ise 
tüm riskleri spektrumun bir parçası kabul edip, risk yönetimi programı kapsamında sistematik olarak bir bütün şeklinde yönetmektir.

Kurumların faaliyet ve hizmetlerini aksatacak, güvenilirliğini zedeleyecek risklerin belirlenmesi ve yönetilmesi, temel stratejilerinin gerçekleştirilebilmesi açısından elzemdir. Bu anlayış ve yaklaşım neticesinde ortaya çıkan risk yönetimi, riskin doğasında bulunan belirsizliklerin oluşturacağı olumsuz etkileri azaltarak kabul edilebilir seviyeye getirmeye çalışan bir disiplindir. Kurumların başarısı, sorunların oluşmadan önlenebilmesi yaklaşımıyla doğrudan ilişkili olduğu için risk yönetimi bu yönde sorunları daha oluşmadan mercek altına alarak olumsuz etkilerini ortadan kaldırmayı hedefleyen proaktif bir yaklaşımdır (Fıkırkoca, 2003). Başka bir ifadeyle risk yönetimi, olası olumsuzluklarla karşılaşma ihtimalini en aza indirmek için birey ve örgütleri aydınlatarak yol göstermek suretiyle çok farklı kaynaklardan gelebilecek risklere karşı alınacak önlemler dizisi olarak da anlaşılabilir (Gao, Sung ve Zhang, 2013, s.677). Bu tanımlamalar ışı̆̆ında risk yönetimini; risklerin belirlenmesi, analizi, değerlendirilmesi, mücadele edilmesi ve izlenmesi süreçlerinde oluşturulan sistematik yönetim politikaları ve prosedürleridir şeklinde açıklayabiliriz.

Kurum ne kadar farklı olasılığa hazır olursa strateji üretmekte o derece kolay olacaktır. Gelecekte karşılaşılabilecek riskli durumlar tanımlanarak kurum için görünürleştirildikçe, hangi stratejilerin geliştirilmesi gerektiği de netleşecek, doğru karar verme olasıllğı artacaktır. Yöneticileri çeşitli ihtimalleri göz önünde bulundurmaya teşvik ederek, belirsizliklerle ilgili aydınlatan risk yönetimi, stratejik planlamanın çerçevesinin oluşturulmasına da zemin hazırlamaktadır. Bu bakımdan risk yönetimi ile stratejik planlama, bir bütünün parçaları olarak birbirlerini tamamlamaktadırlar (Tunç, 2014, s.124).

Yapılan bu açıklamalar doğrultusunda eğitim kurumlarında uygulanacak risk yönetimi ile oluşması muhtemel riskli durumların tahmin edilmesi ve bu risklerin stratejik planlamayla büyük oranda yönetilebilir sınırlar içerisinde tutulması kolay hale gelecektir. Bu kapsamda okullar öncelikli olarak stratejik planlarında belirledikleri amaçların gerçekleştirilmesini sağlayacak hedefler ile oluşabilecek riskler arasında bir denge kurarak önceden belirlemiş oldukları risk iştahlarına (kabul edilebilecek en yüksek risk seviyesi) göre ileriye yönelik hedeflerini belirlemelidirler. Sonrasında durum analizlerinin daha isabetli yapılması, kurumun zayıf ve güçlü yönlerinin, 
tehdit ve fırsatlarının doğru belirlenerek okulda meydana gelebilecek risklerin etkili bir risk yönetim modeli vasitasıyla yönetilmesi gelmektedir.

1992 yılında ABD'de farklı meslek kuruluşlarının bir araya gelerek geliştirdiği iç kontrol risk yönetim modeli; kurumların yürürlükte olan mevzuata uygun şekilde etkin ve verimli çalışması için yönetimin doğru kararlar vermesine yardımcı olmak amacıyla kurumdaki tüm faaliyetlerin sonuçlarının güvenilir düzeyde raporlanması için geliştirilmiştir. İç kontrol tek bir durum veya olay olmayıp, kurum faaliyetlerinin içine nüfuz etmiş hareketler zinciridir. Ayrıca birbiri ile ilişkili birçok unsurdan oluşan iç kontrol idarelerin misyonunu gerçekleştirebilmesi için makul güvence sağlamaya yönelik yönetsel bir araçtır (Saltık, 2007, s.5).

COSO iç kontrol modeli; kontrol ortaml, risk değerlendirmesi, kontrol faaliyetleri, bilgi ve iletişim ile izleme başlıkları altında beş ana bileşenden oluşmaktadır.

Kontrol ortamı bileşeni; etik değerler ve dürüstlük, misyon, organizasyon yapısı, personelin yeterliliği ve performansı ile yetki devri alt bileşenlerinden oluşmaktadır. Kontrol ortamı kurumun sağlıklı işleyebilmesi için oluşturulması gereken altyapı, kural ve kültürle ilgili şartları tanımlayan bileşendir.

Risk değerlendirmesi bileşeni; planlama ve programlama ile risklerin belirlenmesi ve değerlendirilmesi alt bileşenlerinden oluşmaktadır. Risk değerlendirmesi kurumun kısa ve uzun vadeli planlamalarını ve bu planlamada konulan hedeflere ulaşılmasını engelleyebilecek risklerin belirlenmesi ve değerlendirilmesinin nasıl yapılması gerektiği ile ilgili şartları tanımlayan bileşendir.

Kontrol faaliyetleri bileşeni; kontrol stratejileri ve yöntemleri, prosedürlerin belirlenmesi ve belgelendirilmesi, görevler ayrılığı, hiyerarşik kontroller, faaliyetlerin sürekliliği ve bilgi sistemleri kontrolleri alt bileşenlerinden oluşmaktadır. Kurumda belirlenen risklere karşı ne gibi önlemler alınması gerektiğine ilişkin şartları tanımlayan bileşendir.

Bilgi ve iletişim bileşeni; bilgi ve iletişim, raporlama, kayıt ve dosyalama sistemi, hata, usulsüzlük ve yolsuzlukların bildirilmesi alt bileşenlerinden oluşmaktadır. Bilgi ve iletişim kurumda üretilen bilgi ve raporlamaların, kayıt ve dosyalamaların nasıl olması gerektiği ve ayrıca kurum içi ve kurum dışı iletişimin şekline ilişkin şartları tanımlayan bileşendir. 
İzleme bileşeni; iç kontrolün değerlendirilmesi ve iç denetim alt bileşenlerinden oluşmaktadır. İzleme kurumda prosedürlerin ve kontrollerin doğru bir biçimde tasarlanıp tasarlanmadığını, işleyişte hata ve aksama bulunup bulunmadığını, tüm unsurların birbirlerini tamamlayıcı nitelikte etkin ve yeterli çalışıp çalışmadığını belirlemeyi amaçlayan bir bileşendir.

Uluslararası alanda risk yönetim modelleri içerisinde en fazla benimsenen ve kullanılan COSO iç kontrol modeli ülkemizde de 5018 sayılı yasa ile risk yönetim modeli olarak kabul edilmiştir. 2003 yılından itibaren tüm kamu kurumlarının maruz kalabilecekleri riskleri etkili bir şekilde yönetilebilmeleri için birçok alanda mevzuat düzenlemeleri yapılarak iç kontrol sistemine işlerlik kazandırılmaya çalışılmaktadır. Bu kapsamda stratejik plan hazırlama ve uygulama çalışmaları ile risk yönetimi çalışmalarını eşzamanlı yürütmeleri gereken idareler, stratejik planlama için yapılan hazırlık aşamalarında kurumun hedeflerinin neler olduğunun tespiti ile başlayan ve bu hedeflerin öngörüldüğü gibi gerçekleşip gerçekleşmediğinin tahlil edilmesi ile neticelenen bütün aşamalarda iç kontrol bileşenlerini dikkate almaları gerekmektedir (COSO, 2004; KIKKR, 2014, s.31). Ayrıca risk yönetimi araçları vasıtasıyla risk oluşturabilecek çeşitli olasılıkları analiz etmek, stratejik planlama süreçlerinde kurum risklerinin büyük oranda yönetilebilecek sinırlar içinde tutulmasında fayda sağlamaktadır (Tunç, 2014, s.125).

Bu çerçevede okulların hem fiziki mekânları hem de eğitim öğretim süreçlerinde oluşabilecek riskler iç kontrol risk yönetim modeline göre kademeli şekilde zararsız hale getirilmesi ile okulda belirlenen stratejik hedeflere ulaşma olasılığı yükselecek, aynı zamanda öğrenciler için güvenli bir ortam haline gelen okullarda verilen eğitimin niteliği ve verimliliği artacaktır. $\mathrm{Bu}$ bakımdan risk yönetimi, belirsizlik ve stratejilerin birbiriyle etkileşim durumlarını yansıtarak, kurumda geleceğe yönelik alternatif senaryolar üretilebilmesini de sağlamaktadır. Özer'e (2010, s.20) göre risk yönetiminin etkin biçimde uygulanabilmesi için, risk yönetim ilkeleri yöneticiler tarafından planlama sürecine dâhil edilmeli, zaman ve kaynaklar çok iyi kullanılmalldır. Çünkü faaliyetler planlama aşamasındayken, riskler daha kolay değerlendirilip kontrol altına alınabilirler. Bu doğrultuda okullarda yapılan stratejik planlama ile risk yönetiminin bütünleştirilmesi okulların daha etkili yönetilebilmesi açısından büyük kolaylıklar ve fırsatlar sağlayacağı söylenebilir. 
Alanyazında okullarda oluşabilecek risklerin tespiti ve yönetilmesi ile ilgili yapılan çok az sayıda çalışma bulunmaktadır. Bu bağlamda eğitim sisteminin uygulama alanı olan okullarda yapılan stratejik planlama kapsamında durum analizlerinin daha isabetli yapılabilmesi, okulun zayıf ve güçlü yönlerinin, tehdit ve fırsatlarının doğru tespit edilerek, Bakanlığın genel ve özel amaçlarına ulaşılmasına engel olabilecek riskli alanların belirlenmesi, değerlendirilmesi ve bu risklerin doğru yönetilebilmesinin alandaki önemli bir boşluğu dolduracağı ve ayrıca sınırlı sayıda araştırma olan bir alanda uygulamaya yönelik önemli bir veri kaynağı sunacağı düşünülmektedir. Okullar genel anlamda benzer özelliklere sahip olsalar da her okulun kendine has yapısı dikkate alınarak hususi risklerinin belirlenmesi için eğitim alanında bir rehber niteliği taşıyacak olan bu çalışmanın okul yöneticilerine farklı bir bakış açısı kazandırması açısından önemli olacağı beklenmektedir. Bu açıklamalar doğrultusunda araştırmada aşağıdaki problem cümlelerine yanıt aranmıştır.

1. Ortaöğretim okullarında oluşabilecek riskli alanlara ilişkin yönetici ve öğretmen görüşleri nelerdir?

2. Ortaöğretim okullarında oluşabilecek risklerden hangileri yönetici ve öğretmenler tarafından daha önemli görülmektedir?

\section{Yöntem}

Bu araştırmada okul yöneticisi ve öğretmenler tarafından okullarda oluşabilecek risklerin belirlenmesi ve değerlendirilmesi amaciyla genel tarama modeline dayanan betimsel yöntem kullanılmıştır. Tarama yönteminin kullanılma amacı çalışılan evrenin özelliklerini belirleyerek mevcut durumu olduğu gibi açıklayabilmektir (Fraenkel, Wallen ve Hyun, 2012, s.393).

\section{Hedef Evren}

Araştırmanın evrenini, 2017-2018 öğretim yılında Niğde il merkezinde bulunan Milli Eğitim Bakanlığına bağlı kamu liselerinde görev yapan okul yöneticileri ve öğretmenler oluşturmaktadır. Araştırma için örneklem alınmayıp, 2017-2018 öğretim yılında Niğde il merkezinde bulunan Milli Eğitim Bakanlığına bağlı kamu liselerinde görev yapan 95 okul yöneticisi ve 794 öğretmen toplam 889 kişilik evrenin tamamına ulaşılmıştır. Bu okullara 
doldurulması için değerlendirme formları dağıtılmış, geriye dönen 696 adet formdan analizi yapılabilecek olan 672'si değerlendirmeye alınmıştır.

Araştırmaya katılan katılımcıların; 356's1 (\%53) erkek, 316's1 (\%47) kadındır. 17'si (\%2,5) okul müdürü, 57'si (\% 8,5) müdür yardımcısı, 598'i (\%89) öğretmendir. Okul müdürlerinin tamamı (\%100) erkek, müdür yardımclarının 46'sı (\%80,7) erkek, 11'i (\%19,3) kadın, öğretmenlerin 293'ü (\%49) erkek, 305'i (\%51) kadındır. Katılımcıların 81'i (\%12,1) 20-30 yaş arasında, $214^{\prime}$ ü $(\% 31,8)$ 30-40 yaş arasında, 187'si $(\% 27,8)$ 40-50 yaş arasında, 174'ü $(25,9)$ 50-60 yaş arasında, 16'sı (\%2,4) 60 yaşın üzerindedir. Katılımcıların 55'i $(\% 8,2)$ 1-5 yıl arası kıdeme sahip, 122'si $(\% 18,2)$ 6-10 yıl arası kıdeme sahip, 164'ü (\%24,4) 11-15 yıl arası kıdeme sahip, 168'i (\%25) 16-20 yıl arası kıdeme sahip, 163'ü (\%24,3) 20 yıl üzerinde kıdeme sahiptir. Katılımcıların 22'si $(\% 3,3)$ Fen Lisesinde, 233'ü $(\% 34,7)$ Anadolu Lisesinde, 89'u $(\% 13,2)$ İmam Hatip Lisesinde, 294'ü $(\% 43,8)$ Meslek Lisesinde, 24'ü $(\% 3,6)$ Güzel Sanatlar Lisesinde, $10^{\prime} \mathrm{u}(\% 1,5)$ Spor Lisesinde görev yapmaktadır.

\section{Verilerin Analizi}

Araştırma verileri araştırmacılar tarafından geliştirilen "Okul İç Risklerini Değerlendirme Ölçeği” ile toplanmıştır. Ölçek geliştirme süreçleri uygulanarak geçerlik ve güvenirliği test edilen okul iç risklerini değerlendirme ölçeğinde, okul yöneticileri ve öğretmenlerin okul risklerini belirlemeye yönelik beşli derecelemeden oluşan 47 madde bulunmaktadır. Okul iç risklerini değerlendirme ölçeği; yasallık ve etik (yönetici), liderlik - iletişim (yönetici), sınıf yönetimi ve öğretim süreci (öğretmen), mesleki gelişim ve etik (öğretmen), güvenlik ve sağlık boyutlarından oluşmaktadır. Açımlayıcı faktör analizi sonucunda elde edilmiş olan beş alt boyutta toplanan 47 maddelik yapıya, doğrulayıcı faktör analizi uygulanmıştır. Doğrulayıcı faktör analizi sonrasında elde edilen modelin değerlerinin uygun aralıkta olduğu gözlenmiştir (GFI = .89; AGFI = .87; RMSEA $\leq .003$; SRMR $\leq .004$; CFI $\geq .94$; PClose =1). Ölçeğin alt boyutlarına ait Cronbach Alfa katsayıları ise .82 - .91 arasında değişiklik göstermiştir (Ak ve Şahin, 2019). Araştırma kapsamında toplanan verilerin analiz işlemleri aşağıda sırasıyla açılanmıştır.

Araştırmada toplanan verilerin çözümlenmesi için istatistik paket programı (SPSS 21) kullanılmıştır. Okullarda oluşabilecek risklerin değerlendirilmesi amacıyla ilk olarak katılımcıların kişisel bilgileri değerlendirilmek 
amacıyla frekans ve yüzde hesaplamaları yapılmıştır. İkinci aşamada katılımcıların okullarda oluşabilecek risklere ilişkin yapmış oldukları değerlendirmelere ait aritmetik ortalama ve standart sapma değerleri hesaplanmıştır.

Katılımcılardan okullarda oluşabilecek riskleri değerlendirmeleri için olasılık ve etki düzeylerini ayrı ayrı 1 ila 5 puan arasında bir puan vererek değerlendirmeleri istenmiştir. Olasılık ya da etkiye verilen; 1 puanın riskin gerçekleşme olasılığının çok düşük olduğunu ya da gerçekleştiği takdirde etkisinin çok düşük olacağını, 5 puanın ise riskin gerçekleşme olasılı̆̆ının çok yüksek olduğunu ya da gerçekleştiği takdirde etkisinin çok yüksek olacağını ifade etmektedir. Daha sonra her risk için etki ve olasılık puanları kullanılarak bir risk puanı hesaplanmışır. Bu risk puanının hesaplanmasında İç Denetim Koordinasyon Kurulu bünyesinde hazırlanan Kamu İç Denetim Rehberindeki (2013, s.100) "Risk Analizi Modeli" (Tablo 1) esas alınmıştır. $\mathrm{Bu}$ analiz modelinde risklere verilen etki puanlarının olasılık puanlarından daha önemli olduğu varsayımı dikkate alınmıştır.

Tablo 1. Risk Analizi Modeli (Kaynak: KIDR, 2013, s.100)

\begin{tabular}{|c|c|c|c|c|c|c|}
\hline \multirow{2}{*}{\multicolumn{2}{|c|}{ RİSK ANALİZ MODELİ }} & \multicolumn{5}{|l|}{ ETKİ } \\
\hline & & Çok Düşük (1) & Düşük (2) & Orta (3) & Yüksek (4) & Çok Yüksek (5) \\
\hline \multirow{5}{*}{$\begin{array}{l}\text { 当 } \\
\text { 零 }\end{array}$} & Çok Düşük (1) & 1 & 3 & 6 & 10 & 15 \\
\hline & Düşük (2) & 2 & 5 & 9 & 14 & $\underline{19}$ \\
\hline & Orta (3) & 4 & 8 & 13 & 18 & $\underline{\underline{22}}$ \\
\hline & Yüksek (4) & 7 & 12 & 17 & $\underline{\underline{21}}$ & $\underline{24}$ \\
\hline & Çok Yüksek (5) & 11 & 16 & $\underline{20}$ & $\underline{23}$ & $\underline{25}$ \\
\hline
\end{tabular}

Tablo 1'de belirtilen hesaplamalara göre 1-9 puan aralığındaki riskler düşük riskli bölgede, 10-18 puan aralığındaki riskler orta riskli bölgede, 1925 puan aralığındaki riskler ise yüksek riskli bölgede yer alırlar. (Örneğin oluşma olasilı̆̆ 5 , oluştuğu takdirde etkisi 3 olarak puanlanan bir riskin puanı 20 olarak hesaplanmakta ve bu risk yüksek riskli bölgede yer almaktadir.

\section{Bulgular}

Okullarda hangi alanlarda ne tür riskler oluşabileceğinin belirlenmesi kapsamında tespiti yapılan risklerin sayıları ve yüzdeleri verilmiş, sonrasında okullarda oluşabilecek risklerin sınıflandırılması neticesinde oluşan iç risklere ilişkin bilgiler ve her alanda bulunan risklerin sayıları ve yüzdeleri veri- 
lerek açıklanmıştır. Okullarda oluşabilecek risklere ilişkin okul yöneticilerinin ve öğretmenlerin yaptıkları değerlendirme ise aritmetik ortalama ve standart sapma ile açıklanmıştır.

Risklerin değerlendirilmesi kapsamında “Okul İç Risklerini Değerlendirme Ölçeği" ile toplanan veriler öncelikle tüm faktörlerde oluşan ortalamalar ve standart sapma tablosu şeklinde gösterilmiş, devamında ise her faktöre ait risklerin değerlendirmesine ilişkin oluşan ortalamalar ve standart sapmalar sırasıyla verilmiştir.

\section{Okullarda Oluşabilecek Riskli Alanlara İlişkin Okul Yöneticileri ve Ö̆̆- retmenlerin Değerlendirmelerine Ait Bulgular}

Okullarda oluşabilecek riskli alanları tespit etmek için okul yöneticileri ve öğretmenlerin yapmış oldukları değerlendirmelerin aritmetik ortalaması ve standart sapması hesaplanmış ve Tablo 2 ' de verilmiştir.

Tablo 2. Okullarda Oluşabilecek Riskli Alanlara İlişkin Yapılan Değerlendirmelerin Geneline ve Alt Boyutlarna Ait Bulgular

\begin{tabular}{|c|c|c|c|c|}
\hline Ölçek Faktörleri & & $\mathbf{N}$ & $\bar{X}$ & Std. Sapma \\
\hline \multirow{3}{*}{$\begin{array}{l}\text { Yasallık ve Etik } \\
\text { (Yönetici) }\end{array}$} & Olasilık & 672 & 3,19 & ,733 \\
\hline & $\overline{\text { Etki }}$ & 672 & 3,67 &, 510 \\
\hline & Risk Puanı & 672 & 16,27 & 3,270 \\
\hline \multirow{3}{*}{$\begin{array}{l}\text { Liderlik- İletişim } \\
\text { (Yönetici) }\end{array}$} & Olasilık & 672 & 3,14 & ,916 \\
\hline & Etki & 672 & 3,54 & 631 \\
\hline & Risk Puanı & 672 & 15,62 & 4,049 \\
\hline \multirow{3}{*}{$\begin{array}{l}\text { Sınıf Yönetimi ve Öğretim } \\
\text { Süreci (Öğretmen) }\end{array}$} & Olasilık & 672 & 3,11 & 885 \\
\hline & Etki & 672 & 3,53 & ,706 \\
\hline & Risk Puanı & 672 & 15,48 & 4,361 \\
\hline \multirow{3}{*}{$\begin{array}{l}\text { Mesleki Gelişim ve Etik } \\
\text { (Öğretmen) }\end{array}$} & Olasılik & 672 & 3,25 & 833 \\
\hline & Etki & 672 & 3,98 & 487 \\
\hline & Risk Puanı & 672 & 17,74 & 3,374 \\
\hline \multirow{3}{*}{ Güvenlik ve Sağlık } & Olasılık & 672 & 2,96 & 685 \\
\hline & $\overline{\text { Etki }}$ & 672 & 4,05 & ,393 \\
\hline & Risk Puanı & 672 & 17,19 & 2,671 \\
\hline \multirow{3}{*}{ Genel } & Olasılık & 672 & 3,13 & 687 \\
\hline & $\overline{\text { Etki }}$ & 672 & 3,76 & 404 \\
\hline & Risk Puanı* & 672 & 16,49 & 2,850 \\
\hline
\end{tabular}

* Risk puanları olasılık ve etki puanları kullanılarak hesaplanmıştır.

Tablo 2 incelendiğinde, tüm faktörlere ve ölçeğin genel risk puanları ortalamalarının 15-18 puan aralığındaki orta riskli alanda yer aldığı görülmektedir. Olasılık puan ortalaması en yüksek olan faktör $(3,25)$ Mesleki Gelişim 
ve Etik (Öğretmen), etki puan ortalaması en yüksek olan faktör $(4,05) \mathrm{Gü-}$ venlik ve Sağlık, olasılık ve etki puanlarına göre hesaplanan risk puanı ortalaması en yüksek $(17,74)$ olan faktör ise ile yine Mesleki Gelişim ve Etik (Ö̆̆retmen) faktörüdür.

Etki ve olasılık puan ortalamaları arasındaki farkın en yüksek olduğu $(1,09)$ faktör "Güvenlik ve Sağlık", puan ortalamaları arasındaki farkın en düşük olduğu $(0,40)$ faktör ise "Liderlik-İletişim (Yönetici)" faktörüdür. Tüm faktörlerde ve ölçeğin genelinde olasılık puan ortalamalarının etki puan ortalamalarından düşük olduğu görülmektedir.

Okullarda oluşabilecek risklerin okul yöneticileri ve öğretmenler tarafından boyutlara göre değerlendirmelerinin aritmetik ortalamaları ve standart sapmaları hesaplanmış ve aşağıda tablolar halinde sırasıyla verilmiştir.

Okul İç Risklerini Değerlendirme Ölçeğinin Yasallık Ve Etik (Yönetici) Faktörü Kapsamında Oluşabilecek Risklere İlişkin Okul Yöneticileri Ve Ö̆̆retmenler Tarafından Yapılan Değerlendirmelere Ait Bulgular

Okul yöneticileri ve öğretmenlerin Yasallık ve Etik (Yönetici) faktörü kapsamında oluşabilecek risklere ilişkin yapmış olduklanı değerlendirmelerin aritmetik ortalaması ve standart sapması hesaplanmış ve Tablo 3'de gösterilmiştir.

Tablo 3. Yasallık ve Etik (Yönetici) Faktörüne İlişkin Yapılan Değerlendirmelere Ait Bulgular

\begin{tabular}{|c|c|c|c|c|}
\hline \multicolumn{2}{|l|}{ Yasallık ve Etik (Yönetici) Faktörü } & \multirow{2}{*}{$\begin{array}{l}\mathbf{N} \\
672 \\
\end{array}$} & \multirow{2}{*}{\begin{tabular}{l|l}
$X$ \\
3,11 \\
\end{tabular}} & \multirow{2}{*}{$\begin{array}{l}\text { Std. Sapma } \\
1,084 \\
\end{array}$} \\
\hline Stratejik planda kurumun vizyon, misyon ve hedef- & Olasilık & & & \\
\hline \multirow[t]{2}{*}{ lerinin gerçekçi olarak belirlenmemesi } & Etki & 672 & 3,57 & 1,083 \\
\hline & Risk Puanı & 672 & 15,67 & 6,198 \\
\hline \multirow{3}{*}{$\begin{array}{l}\text { Kurumun hedeflerine ulaşmasını } \\
\text { engelleyecek riskler belirlenerek } \\
\text { alınacak önlemlerin alınmaması } \\
\end{array}$} & Olasilık & 672 & 3,63 & 1,231 \\
\hline & Etki & 672 & 4,08 & 1,003 \\
\hline & Risk Puanı & 672 & 19,07 & 5,709 \\
\hline \multirow{3}{*}{$\begin{array}{l}\text { Seminer çalışmaları ile ilgili gerekli planlama } \\
\text { ve takibin yapılmaması }\end{array}$} & Olasilık & 672 & 3,11 & 1,180 \\
\hline & Etki & 672 & 2,57 & 1,143 \\
\hline & Risk Puan1 & 672 & 11,42 & 6,221 \\
\hline \multirow[t]{3}{*}{ Yöneticilerin denetim görevlerini aksatmaları } & Olasılık & 672 & 3,26 & ,998 \\
\hline & Etki & 672 & 4,49 & 697 \\
\hline & Risk Puanı & 672 & 20,13 & 3,879 \\
\hline \multirow{3}{*}{$\begin{array}{l}\text { Ders programı, sınav görevi, nöbet vb. } \\
\text { konularda görevlendirmeler yapılırken } \\
\text { bazı çalışanlara ayrıcalıklı davranılması }\end{array}$} & Olasılık & 672 & 3,73 & 1,191 \\
\hline & Etki & 672 & 3,23 & 1,123 \\
\hline & Risk Puanı & 672 & 16,30 & 6,194 \\
\hline
\end{tabular}




\begin{tabular}{|c|c|c|c|c|}
\hline \multirow{3}{*}{$\begin{array}{l}\text { Ÿ̈neticilerin maaş ya da ek ders ücreti } \\
\text { karşılığı girmeleri gereken derslere girmemeleri }\end{array}$} & Olasilık & 672 & 3,66 & 1,332 \\
\hline & Etki & 672 & 3,07 & 1,262 \\
\hline & Risk Puanı & 672 & 15,35 & 6,653 \\
\hline \multirow{3}{*}{$\begin{array}{l}\text { Personelin özlük işlemlerinin tam ve zamanında } \\
\text { yapılmaması }\end{array}$} & Olasılık & 672 & 3,25 & 1,391 \\
\hline & Etki & 672 & 3,92 & 1,119 \\
\hline & Risk Puanı & 672 & 17,30 & 6,551 \\
\hline \multirow{3}{*}{$\begin{array}{l}\text { Objektif performans değerlendirme kıstasları belir- } \\
\text { lenmeden kişisel algılara göre ödüllendirmelerin } \\
\text { yapılması }\end{array}$} & Olasılık & 672 & 3,16 & 1,426 \\
\hline & Etki & 672 & 3,98 & 1,143 \\
\hline & Risk Puanı & 672 & 17,19 & 6,749 \\
\hline \multirow[t]{3}{*}{ Okula yapılan bağışların makbuzsuz elden alınması } & Olasilık & 672 & 2,71 & 1,278 \\
\hline & Etki & 672 & 4,00 & 1,076 \\
\hline & Risk Puanı & 672 & 16,29 & 6,163 \\
\hline \multirow{3}{*}{$\begin{array}{l}\text { Mevzuatta olmayan görevleri yapmak istemeyen } \\
\text { personele yöneticilerin mobbing (yıldırma-bezdirme) } \\
\text { uygulaması }\end{array}$} & Olasilık & 672 & 2,95 & 1,310 \\
\hline & Etki & 672 & 3,74 & 1,159 \\
\hline & Risk Puanı & 672 & 15,72 & 6,833 \\
\hline \multirow{3}{*}{$\begin{array}{l}\text { Kuruma gelen resmi yazıların ilgili kişiye tebligatının } \\
\text { zamanında yapılmaması }\end{array}$} & Olasilık & 672 & 2,61 & 1,226 \\
\hline & Etki & 672 & 3,77 & 1,111 \\
\hline & Risk Puanı & 672 & 14,97 & 6,137 \\
\hline \multirow[t]{3}{*}{ Yöneticilerin keyfi olarak mevzuatın dışına çıkmaları } & Olasilık & 672 & 2,99 & 1,182 \\
\hline & Etki & 672 & 3,46 & 1,087 \\
\hline & Risk Puanı & 672 & 14,77 & 6,421 \\
\hline \multirow{3}{*}{$\begin{array}{l}\text { Okulda tutulması gereken belge, defter, çizelge ve } \\
\text { formların doğru şekilde tutulmaması }\end{array}$} & Olasilık & 672 & 2,71 & 1,455 \\
\hline & Etki & 672 & 3,45 & 1,333 \\
\hline & Risk Puanı & 672 & 13,89 & 7,483 \\
\hline \multirow{3}{*}{$\begin{array}{l}\text { Kurallara uymayan öğrenciler için disiplin hükümle- } \\
\text { rinin uygulanmaması }\end{array}$} & Olasilık & 672 & 3,88 & 1,323 \\
\hline & Etki & 672 & 4,10 & 1,084 \\
\hline & Risk Puanı & 672 & 19,83 & 5,551 \\
\hline \multirow{3}{*}{ Toplam } & Olasılık & 672 & 3,19 & ,733 \\
\hline & Etki & 672 & 3,67 &, 510 \\
\hline & Risk Puanı & 672 & 16,27 & 3,270 \\
\hline
\end{tabular}

Tablo 3 incelendiğinde; yöneticilerin Yasallık ve Etik (Yönetici) faktörü altındaki 2 numaralı "Kurumun hedeflerine ulaşmasını engelleyecek riskler belirlenerek alınacak önlemlerin alınmaması" riskinin, 4 numaralı "Yöneticilerin denetim görevlerini aksatmaları" riskinin ve 14 numaralı "Kurallara uymayan öğrenciler için disiplin hükümlerinin uygulanmaması" riskinin puanının yüksek (19 puan üzerinde) olduğu, 5 numaralı "Ders programı, sınav görevi, nöbet vb. konularda görevlendirmeler yapılırken bazı çalışanlara ayrıcalıklı (olumlu ya da olumsuz) davranılması" riskinin, 7 numaralı "Personelin özlük işlemlerinin tam ve zamanında yapılmaması" riskinin ve 8 numaralı "Objektif performans değerlendirme kıstasları belirlenmeden kişisel algılara göre ödüllendirmelerin yapılması" riskinin puanları yüksek- 
orta riskli alanda (16-19 puan arası), diğer risklerin ise düşük-orta riskli alanda (10-16 puan arası) yer aldığı görülmektedir.

Yüksek riskli olan maddeler arasında 4 numaralı "Yöneticilerin denetim görevlerini aksatmaları" riskinin etki puanı ile olasılık puanı arasındaki puan farkı 1'den yüksek (etki: 4,49 - olasılık: 3,26), diğer 2 numaralı “Kurumun hedeflerine ulaşmasını engelleyecek riskler belirlenerek alınacak önlemlerin alınmaması" (etki: 4,08 - olasılık: 3,63) riskinin ve 14 numaralı "Kurallara uymayan öğrenciler için disiplin hükümlerinin uygulanmaması" (etki: 4,10 - olasılık: 3,88) riskinin etki ve olasılık puanları birbirine yakın ve 1 puandan az fark olduğu görülmektedir.

Orta riskli olan maddeler arasında ise 9 numaralı "Okula yapılan bağışların makbuzsuz elden alınması" riskinin (etki: 4,00 - olasılık: 2,71) ve 11 numaralı "Kuruma gelen resmi yazıların ilgili kişiye tebligatının zamanında yapılmaması" riskinin (etki: 3,77 - olasılık: 2,61) etki puanı ile olasılık puanı arasındaki puan farkının 1'den yüksek, diğer orta risk puan aralı̆̆ında bulunan 1 numaralı "Stratejik planda kurumun vizyon, misyon ve hedeflerinin gerçekçi olarak belirlenmemesi" riskinin, 3 numaralı "Seminer çalışmaları ile ilgili gerekli planlama ve takibin yapılmaması" riskinin, 5 numaralı "Ders program1, sinav görevi, nöbet vb. konularda görevlendirmeler yap1lırken bazı çalışanlara ayrıcalıklı (olumlu ya da olumsuz) davranılması" riskinin, 6 numaralı "Yöneticilerin maaş ya da ek ders ücreti karşıllğı girmeleri gereken derslere girmemeleri" riskinin, 7 numaralı "Personelin özlük işlemlerinin tam ve zamanında yapılmaması" riskinin, 8 numaralı "Objektif performans değerlendirme kıstasları belirlenmeden kişisel algılara göre ödüllendirmelerin yapılması" riskinin, 10 numaralı "Mevzuatta olmayan görevleri yapmak istemeyen personele yöneticilerin mobbing (yıldırmabezdirme) uygulaması" riskinin, 12 numaralı "Yöneticilerin keyfi olarak mevzuatın dışına çıkmaları" riskinin ve 13 numaralı "Okulda tutulması gereken belge, defter, çizelge ve formların doğru şekilde tutulmaması" riskinin etki ve olasılık puanlarının birbirine yakın ve 1 puandan az fark olduğu, bu riskler arasında 3 numaralı "Seminer çalışmaları ile ilgili gerekli planlama ve takibin yapılmaması" riskinin en düşük risk puanına (11,42 puan) sahip olduğu görülmektedir. Ayrıca 3. 5. ve 6 numaralı risklerin haricinde diğer risklerin etki puanlarının olasılık puanlarından daha yüksek puana sahip oldukları görülmektedir. 
Okul İç Risklerini Değerlendirme Ölçeğinin Liderlik-İletişim (Yönetici) Faktörü Kapsamında Oluşabilecek Risklere İlişkin Okul Yöneticileri Ve Öğretmenler Tarafindan Yapılan Değerlendirmelere Ait Bulgular

Okul yöneticileri ve öğretmenlerin Liderlik- İletişim (Yönetici) faktörü kapsamında oluşabilecek risklere ilişkin yapmış olduklan değerlendirmelerin aritmetik ortalaması ve standart sapması hesaplanmış ve Tablo 4 'de verilmiştir.

Tablo 4. Liderlik - İletişim (Yönetici) Faktörüne İlişkin Yapılan Değerlendirmelere Ait Bulgular

\begin{tabular}{|c|c|c|c|c|}
\hline Liderlik- İletişim (Yönetici) & & $\mathbf{N}$ & $\bar{X}$ & Std. Sapma \\
\hline \multirow{3}{*}{$\begin{array}{l}\text { Yöneticilerin okul çalışanlarının düşüncelerine } \\
\text { başvurmadan kararlar alması }\end{array}$} & Olasilik & 672 & 3,90 & 1,111 \\
\hline & Etki & 672 & 2,96 & 1,262 \\
\hline & Risk Puanı & 672 & 15,67 & 6,195 \\
\hline \multirow{3}{*}{$\begin{array}{l}\text { Okul çalışanlarına gerektiği ölçüde yetki devri } \\
\text { yapılmaması }\end{array}$} & Olasilık & 672 & 2,82 & 1,312 \\
\hline & Etki & 672 & 3,61 & 1,101 \\
\hline & Risk Puanı & 672 & 14,83 & 6,621 \\
\hline \multirow{3}{*}{$\begin{array}{l}\text { Yöneticilerin insani ilişkilerinde nezaket kurallarına } \\
\text { uymayarak kaba davranışlar sergilemesi }\end{array}$} & Olasilık & 672 & 2,90 & 1,399 \\
\hline & Etki & 672 & 3,86 & 1,118 \\
\hline & Risk Puanı & 672 & 15,96 & 6,632 \\
\hline \multirow{3}{*}{$\begin{array}{l}\text { Çalışanların mesleki ve kişisel gelişim faaliyetlerine } \\
\text { katılmaları yönünde teşvik edilmemeleri }\end{array}$} & Olasilık & 672 & 2,72 & 1,187 \\
\hline & Etki & 672 & 3,39 & 1,104 \\
\hline & Risk Puanı & 672 & 13,76 & 6,573 \\
\hline \multirow{3}{*}{$\begin{array}{l}\text { Sosyal ilişkilerin yönetiminde zayıf kalan yöneticile- } \\
\text { rin kurum çalışanlarını bütünleştirici yönde motive } \\
\text { edememesi }\end{array}$} & Olasilık & 672 & 2,74 & 1,329 \\
\hline & Etki & 672 & 3,62 & 1,142 \\
\hline & Risk Puanı & 672 & 14,73 & 6,648 \\
\hline \multirow{3}{*}{$\begin{array}{l}\text { Yöneticilerin bilgisayar, akıllı telefon ve benzeri } \\
\text { teknolojik cihazları görevin gerektirdiği ölçüde } \\
\text { kullanamaması }\end{array}$} & Olasilık & 672 & 3,53 & 1,347 \\
\hline & Etki & 672 & 3,00 & 1,251 \\
\hline & Risk Puanı & 672 & 14,68 & 6,559 \\
\hline \multirow{3}{*}{$\begin{array}{l}\text { Çalışanlar arasında ideolojik, siyasal ve sendikal } \\
\text { gruplaşmalara engel olacak ilkelerin belirlenerek } \\
\text { uygulanmaması }\end{array}$} & Olasilık & 672 & 3,43 & 1,257 \\
\hline & Etki & 672 & 4,36 & 807 \\
\hline & Risk Puanı & 672 & 19,74 & 4,930 \\
\hline \multirow{3}{*}{ Toplam } & Olasılık & 672 & 3,14 & ,916 \\
\hline & Etki & 672 & 3,54 & 631 \\
\hline & Risk Puanı & 672 & 15,62 & 4,049 \\
\hline
\end{tabular}

Tablo 4 incelendiğinde; Yöneticilerin Liderlik- İletişim faktörü altındaki 21 numaralı "Çalışanlar arasında ideolojik, siyasal ve sendikal gruplaşmalara engel olacak ilkelerin belirlenerek uygulanmaması" riskinin puanı yüksek (19 puan üzerinde), diğer risklerin puanlarının ise düşük-orta riskli alanda (10-16 puan arası) yer aldığı görülmektedir. 
Yüksek riskli çıkan 21 numaralı "Çalışanlar arasında ideolojik, siyasal ve sendikal gruplaşmalara engel olacak ilkelerin belirlenerek uygulanmaması" riskinin etki puanı ile olasılık puanı arasındaki farkın 1'e yakın (etki: 4,36 olasılık: 3,43) olduğu görülmektedir.

Orta riskli olan maddeler arasında ise 15 numaralı "Yöneticilerin okul çalışanlarının düşüncelerine başvurmadan kararlar alması" riskinin (etki: 2,96; olasılık: 3,90), 17 numaralı "Yöneticilerin insani ilişkilerinde nezaket kurallarına uymayarak kaba davranışlar sergilemesi" riskinin (etki: 3,86 - olasılık: 2,90 ) ve 19 numaralı "Sosyal ilişkilerin yönetiminde zayıf kalan yöneticilerin kurum çalışanlarını bütünleştirici yönde motive edememesi" riskinin (etki: 3,62 - olasılık: 2,74) etki puanı ile olasılık puanı arasındaki puan farkının 1'e yakın olduğu, diğer orta risk puanına sahip; 16 numaralı "Okul çalışanlarına gerektiği ölçüde yetki devri yapılmaması" riskinin, 18 numaralı "Çalışanların mesleki ve kişisel gelişim faaliyetlerine katılmaları yönünde teşvik edilmemeleri" riskinin ve 20 numaralı "Yöneticilerin bilgisayar, akıllı telefon ve benzeri teknolojik cihazları görevin gerektirdiği ölçüde kullanamaması" riskinin etki ve olasılık puanlarının birbirine yakın ve puan farkının 1 puandan az olduğu görülmektedir.

Bu riskler arasında 18 numaralı "Çalışanların mesleki ve kişisel gelişim faaliyetlerine katılmaları yönünde teşvik edilmemeleri" riskinin en düşük risk puanına (13,76 puan) sahip olduğu ve 15 numaralı risk hariç genel olarak tüm maddelerin etki puanlarının olasılık puanlarından yüksek olduğu görülmektedir.

Okul İ̧ Risklerini Değerlendirme Ölçeğinin Sınf Yönetimi ve Öğretim Süreci (Öğretmen) Faktörü Kapsamında Oluşabilecek Risklere İlişkin Okul Yöneticileri Ve Öğretmenler Tarafından Yapılan Değerlendirmelere Ait Bulgular

Okul yöneticileri ve öğretmenlerin Sınıf Yönetimi ve Öğretim Süreci (Öğretmen) faktörü kapsamında oluşabilecek risklere ilişkin yapmış oldukları değerlendirmelerin aritmetik ortalaması ve standart sapması hesaplanmış ve Tablo 5 'de verilmiştir. 
Tablo 5. Sını Yönetimi ve Öğretim Süreci (Öğretmen) Faktörüne İlişkin Yapılan Değerlendirmelere Ait Bulgular

\begin{tabular}{|c|c|c|c|c|}
\hline $\begin{array}{l}\text { Sınıf Yönetimi ve Öğretim Süreci } \\
\text { (Öğretmen) }\end{array}$ & & $\mathbf{N}$ & $X$ & $\begin{array}{l}\text { Std. } \\
\text { Sapma }\end{array}$ \\
\hline \multirow{3}{*}{$\begin{array}{l}\text { Sınıftaki öğrencileri olumlu ya da olumsuz etkileye- } \\
\text { bilecek öğrencilerin tespit edilmemesi }\end{array}$} & Olasilık & 672 & 3,02 & 1,159 \\
\hline & Etki & 672 & 3,46 & 1,066 \\
\hline & Risk Puanı & 672 & 14,98 & 6,357 \\
\hline \multirow{3}{*}{$\begin{array}{l}\text { Yapılan etkinliklerde her öğrenciye öğrendiklerini } \\
\text { paylaşması için yeterli fırsat verilmemesi }\end{array}$} & Olasılık & 672 & 3,19 & 1,216 \\
\hline & Etki & 672 & 3,37 & 1,082 \\
\hline & Risk Puanı & 672 & 15,08 & 6,265 \\
\hline \multirow{3}{*}{$\begin{array}{l}\text { Müfredattaki } \\
\text { işlenmesi }\end{array}$} & Olasılık & 672 & 3,01 & 1,334 \\
\hline & Etki & 672 & 3,68 & 1,155 \\
\hline & Risk Puanı & 672 & 15,63 & 6,731 \\
\hline \multirow{3}{*}{$\begin{array}{l}\text { Öğrencilerin öğrenme özellikleri ve ders seviyeleri- } \\
\text { nin doğru belirlenmemesi }\end{array}$} & Olasılık & 672 & 3,48 & 1,309 \\
\hline & Etki & 672 & 3,99 & 1,070 \\
\hline & Risk Puanı & 672 & 18,41 & 5,817 \\
\hline \multirow{3}{*}{$\begin{array}{l}\text { Üst düzey düşünme becerilerinin sergilenebileceği } \\
\text { etkinlikler tasarlanarak öğrencilere kazandırılama- } \\
\text { ması }\end{array}$} & Olasilık & 672 & 3,06 & 1,192 \\
\hline & Etki & 672 & 3,46 & 1,076 \\
\hline & Risk Puanı & 672 & 14,97 & 6,351 \\
\hline \multirow{3}{*}{$\begin{array}{l}\text { Modern öğretim yöntem ve teknikleri kullanılarak } \\
\text { öğrenciyi merkeze alacak şekilde ders işlenmemesi }\end{array}$} & Olasılık & 672 & 3,09 & 1,116 \\
\hline & Etki & 672 & 3,53 & 1,057 \\
\hline & Risk Puanı & 672 & 15,51 & 6,196 \\
\hline \multirow{3}{*}{$\begin{array}{l}\text { Süreklilik gösteren olumsuz öğrenci davranışlarının } \\
\text { öğretmenler tarafından görmezden gelinmesi }\end{array}$} & Olasilik & 672 & 3,04 & 1,191 \\
\hline & Etki & 672 & 3,40 & 1,002 \\
\hline & Risk Puanı & 672 & 14,77 & 6,188 \\
\hline \multirow{3}{*}{$\begin{array}{l}\text { Öğretmenlerin derslerde sesini, jest ve mimiklerini } \\
\text { ve beden dilini gerektiğinden fazla ya da az kullan- } \\
\text { ması }\end{array}$} & Olasilık & 672 & 3,00 & 1,241 \\
\hline & Etki & 672 & 3,39 & 1,083 \\
\hline & Risk Puanı & 672 & 14,57 & 6,568 \\
\hline \multirow{3}{*}{ Toplam } & Olasılık & 672 & 3,11 & 885 \\
\hline & Etki & 672 & 3,53 & ,706 \\
\hline & Risk Puanı & 672 & 15,48 & 4,361 \\
\hline
\end{tabular}

Tablo 5 incelendiğinde; öğretmenlerin sınıf yönetimi ve öğretim süreci kategorisi altındaki 25 numaralı "Öğrencilerin öğrenme özellikleri ve ders seviyelerinin doğru belirlenmemesi" riskinin yüksek risk puanına (19 puana yakın) sahip olduğu, diğer risklerin ise düşük-orta riskli alanda (10-16 puan arası) yer aldığı görülmektedir.

Yüksek riskli çıan 25 numaralı "Öğrencilerin öğrenme özellikleri ve ders seviyelerinin doğru belirlenmemesi" riskinin etki puanı ile olasılık puanının birbirine yakın (etki: 3,99, olasılık: 3,48) olduğu görülmektedir.

Orta riskli alanda yer alan risklerin etki puanları ile olasılık puanlarının birbirine yakın olduğu, bu riskler arasında 29 numaralı "Öğretmenlerin derslerde sesini, jest ve mimiklerini ve beden dilini gerektiğinden fazla ya da az kullanması" riskinin en düşük risk puanına (14,57 puan) sahip olduğu 
ve bu kategorideki tüm risklerin etki puanlarının olasılık puanlarından yüksek olduğu görülmektedir.

Okul İç Risklerini Değerlendirme Ölçeğinin Mesleki Gelişim Ve Etik (Öğretmen) Faktörü Kapsamında Oluşabilecek Risklere İlişkin Okul Yöneticileri Ve Öğretmenler Tarafindan Yapılan Değerlendirmelere Ait Bulgular

Okul yöneticileri ve öğretmenlerin Mesleki Gelişim ve Etik (Öğretmen) faktörü kapsamında oluşabilecek risklere ilişkin yapmış oldukları değerlendirmelerin aritmetik ortalaması ve standart sapması hesaplanmış ve Tablo $6^{\prime}$ da verilmiştir.

Tablo 6. Mesleki Gelişim ve Etik (Öğretmen) Faktörüne İlişkin Yapılan Değerlendirmelere Ait Bulgular

\begin{tabular}{|c|c|c|c|c|}
\hline Mesleki Gelişim ve Etik (Öğretmen) & & $\mathbf{N}$ & $\bar{x}$ & $\begin{array}{l}\text { Std. } \\
\text { Sapma }\end{array}$ \\
\hline \multirow{3}{*}{$\begin{array}{l}\text { Öğretmenlerin alanlarıyla ilgili yayımlanan yazıları } \\
\text { takip etmemeleri }\end{array}$} & Olasılık & 672 & 2,94 & 1,386 \\
\hline & Etki & 672 & 3,55 & 1,179 \\
\hline & Risk Puanı & 672 & 14,93 & 7,025 \\
\hline \multirow{3}{*}{$\begin{array}{l}\text { Öğretmenlerin aldıkları lisans ve formasyon eğitimi- } \\
\text { nin niteliğinin verecekleri ders-konu için yeterli } \\
\text { olmaması }\end{array}$} & Olasılık & 672 & 3,38 & 1,188 \\
\hline & Etki & 672 & 4,49 & ,653 \\
\hline & Risk Puanı & 672 & 20,31 & 3,977 \\
\hline \multirow{3}{*}{$\begin{array}{l}\text { Kişisel-psikolojik sorunları olan öğretmenlerin } \\
\text { yaşadıkları sorunları sınıfa yansıtmaları }\end{array}$} & Olasilık & 672 & 3,76 & 1,153 \\
\hline & Etki & 672 & 4,38 & ,745 \\
\hline & Risk Puanı & 672 & 20,81 & 4,212 \\
\hline \multirow{3}{*}{$\begin{array}{l}\text { Öğretmenlerin alanları ile ilgili teknolojik eğitim- } \\
\text { öğretim materyallerini etkili kullanamaması }\end{array}$} & Olasilık & 672 & 3,09 & 1,224 \\
\hline & Etki & 672 & 3,45 & 1,082 \\
\hline & Risk Puanı & 672 & 15,05 & 6,545 \\
\hline \multirow{3}{*}{$\begin{array}{l}\text { Deneyimli öğretmenlerin aday öğretmenleri yetiş- } \\
\text { tirmek için yeterli zaman ayırmamaları }\end{array}$} & Olasilık & 672 & 3,14 & 1,341 \\
\hline & Etki & 672 & 3,67 & 1,119 \\
\hline & Risk Puanı & 672 & 16,03 & 6,514 \\
\hline \multirow{3}{*}{$\begin{array}{l}\text { Öğretmenlerin ders yılı içerisinde izin ya da sağlık } \\
\text { raporunu aşırı kullanmaları }\end{array}$} & Olasilık & 672 & 2,91 & 1,223 \\
\hline & Etki & 672 & 4,09 & ,988 \\
\hline & Risk Puanı & 672 & 17,21 & 5,883 \\
\hline \multirow{3}{*}{$\begin{array}{l}\text { Öğretmenlerin okulda belirlenen giriş-çıkış saatleri- } \\
\text { ne ve çalışma-dinlenme sürelerine uymaması }\end{array}$} & Olasılık & 672 & 3,48 & 1,308 \\
\hline & Etki & 672 & 3,87 & 1,087 \\
\hline & Risk Puanı & 672 & 17,95 & 6,124 \\
\hline \multirow{3}{*}{$\begin{array}{l}\text { Öğretmenin öğrencileri ile saygın bir ilişki geliştire- } \\
\text { memesi }\end{array}$} & Olasilık & 672 & 3,34 & 1,378 \\
\hline & Etki & 672 & 4,41 & 812 \\
\hline & Risk Puanı & 672 & 19,68 & 4,851 \\
\hline \multirow{3}{*}{ Toplam } & Olasılık & 672 & 3,25 & 833 \\
\hline & Etki & 672 & 3,98 & 487 \\
\hline & Risk Puanı & 672 & 17,74 & 3,374 \\
\hline
\end{tabular}


Tablo 6 incelendiğinde; Öğretmenlerin Mesleki Gelişim ve Etik Faktörü altındaki 31 numaralı "Öğretmenlerin aldıkları lisans ve formasyon eğitiminin niteliğinin verecekleri ders-konu için yeterli olmaması" riskinin, 32 numaralı "Kişisel-psikolojik sorunları olan öğretmenlerin yaşadıkları sorunları sınıfa yansıtmaları" riskinin ve 37 numaralı "Öğretmenin öğrencileri ile saygın bir ilişki geliştirememesi" riskinin puanının yüksek (19 puan üzerinde) olduğu, 35 numaralı "Öğretmenlerin ders yılı içerisinde izin ya da sağlık raporunu aşırı kullanmaları" riskinin ve 36 numaralı "Öğretmenlerin okulda belirlenen giriş-çıkış saatlerine ve çalışma-dinlenme sürelerine uymaması" riskinin puanının yüksek orta riskli alanda (16-19 puan arası), diğer risklerin ise düşük orta riskli alanda (10-16 puan arası) yer aldığı görülmektedir.

Yüksek riskli olan maddeler arasında 31 numaralı “Öğretmenlerin aldıkları lisans ve formasyon eğitiminin niteliğinin verecekleri ders-konu için yeterli olmaması" riskinin (etki: 4,49 - olasılık: 3,38) ve 37 numaralı "Öğretmenin öğrencileri ile saygin bir ilişki geliştirememesi" riskinin (etki: 4,41olasılık: 3,34) etki puanı ile olasılık puanı arasındaki puan farkının 1'den fazla, yüksek puanlı diğer 32 numaralı "Kişisel-psikolojik sorunları olan öğretmenlerin yaşadıkları sorunları sınıfa yansıtmaları" riskinin (etki: 4,38olasılık: 3,76) etki ve olasılık puanlarının birbirine yakın ve aralarında 1 puandan az fark olduğu görülmektedir.

Orta riskli olan maddeler arasında ise 35 numaralı "Öğretmenlerin ders yılı içerisinde izin ya da sağlık raporunu aşırı kullanmaları" riskinin (etki: 4,09; olasılık: 2,91) etki puanı ile olasılık puanı arasındaki puan farkının 1 'den fazla olduğu, diğer orta risk puanına sahip 36 numaralı “Öğretmenlerin okulda belirlenen giriş-çıkış saatlerine ve çalışma-dinlenme sürelerine uymaması" riskinin (etki: 3,87- olasılık: 3,48), 30 numaralı "Öğretmenlerin alanlarıyla ilgili yayımlanan yazıları takip etmemeleri" riskinin (etki: 3,55; olasılık: 2,94), 33 numaralı "Öğretmenlerin alanları ile ilgili teknolojik eğitim-öğretim materyallerini etkili kullanamaması" riskinin (etki: 3,45- olasilık: 3,09) ve 34 numaralı “Deneyimli öğretmenlerin aday öğretmenleri yetiştirmek için yeterli zaman ayırmamaları" riskinin (etki: 3,67; olasılık: 3,14) etki ve olasılık puanlarının birbirine yakın ve aralarında 1 puandan az fark olduğu görülmektedir. Bu riskler arasında 30 numaralı "Öğretmenlerin alanlarıyla ilgili yayımlanan yazıları takip etmemeleri" riskinin en düşük 
risk puanına (14,93 puan) sahip olduğu ve tüm risklerin etki puanlarının olasılık puanlarından yüksek olduğu görülmektedir.

\section{Okul İ̧̧ Risklerini Değerlendirme Ölçeğinin Güvenlik Ve Sağlik Faktörü Kapsamında Oluşabilecek Risklere İlişkin Okul Yöneticileri Ve Öğretmen- ler Tarafindan Yapilan Değerlendirmelere Ait Bulgular}

Okul yöneticileri ve öğretmenlerin Güvenlik ve Sağlık faktörü kapsamında oluşabilecek risklere ilişkin yapmış oldukları değerlendirmelerin aritmetik ortalaması ve standart sapması hesaplanmış ve Tablo 7'de verilmiştir.

Tablo 7. Güvenlik ve Sağlik Faktörüne İlişkin Yapılan Değerlendirmelere Ait Bulgular

\begin{tabular}{|c|c|c|c|c|}
\hline Güvenlik ve Sağlık & & $\mathbf{N}$ & $\bar{X}$ & Std. Sapma \\
\hline \multirow{3}{*}{$\begin{array}{l}\text { Öğrenci oyun alanlarındaki oyun araçlarının (kale, pota, } \\
\text { kaydırak vs.) düzenli bakımlarının yapılmaması }\end{array}$} & Olasilık & 672 & 3,54 & 1,335 \\
\hline & Etki & 672 & 3,85 & 1,112 \\
\hline & Risk Puanı & 672 & 17,96 & 6,284 \\
\hline \multirow{3}{*}{$\begin{array}{l}\text { Okulda ve yakın çevresinde kırık pencere ve kapı, korku- } \\
\text { luksuz balkon ve merdiven, kapısız asansör boşluğu, fos- } \\
\text { septik çukur ve benzeri tehlikelerin olması }\end{array}$} & Olasilık & 672 & 4,43 & 876 \\
\hline & Etki & 672 & 4,58 & ,590 \\
\hline & Risk Puanı & 672 & 23,03 & 2,757 \\
\hline \multirow{3}{*}{$\begin{array}{l}\text { Okulun ısıtma ve soğutma sistemlerinin sağlıklı } \\
\text { çalışmaması }\end{array}$} & Olasıllk & 672 & 3,02 & 1,424 \\
\hline & Etki & 672 & 3,82 & 1,167 \\
\hline & Risk Puanı & 672 & 16,21 & 6,784 \\
\hline \multirow{3}{*}{$\begin{array}{l}\text { Okuldaki elektrik ve doğalgaz tesisatlarının bakım- } \\
\text { onarımlarının düzenli yapılmaması }\end{array}$} & Olasilık & 672 & 2,50 & 1,005 \\
\hline & Etki & 672 & 4,15 & ,981 \\
\hline & Risk Puanı & 672 & 16,40 & 5,315 \\
\hline \multirow{3}{*}{$\begin{array}{l}\text { Acil durum eylem planları hazırlanarak doğal afet tatbikat- } \\
\text { larının belirli periyotlarla yapılmaması }\end{array}$} & Olasilık & 672 & 2,70 & 1,071 \\
\hline & Etki & 672 & 4,38 & ,913 \\
\hline & Risk Puanı & 672 & 17,92 & 5,222 \\
\hline \multirow{3}{*}{$\begin{array}{l}\text { Okulda ve pansiyonlarda öğrencilerin istismara uğramama- } \\
\text { ları yönünde gerekli önlemlerinin alınmaması }\end{array}$} & Olasilık & 672 & 2,52 & ,900 \\
\hline & Etki & 672 & 4,77 & ,441 \\
\hline & Risk Puanı & 672 & 19,25 & 3,452 \\
\hline \multirow{3}{*}{$\begin{array}{l}\text { Okul dışı mekânlara yapılan gezilerde gerekli } \\
\text { önlemlerin alınmaması }\end{array}$} & Olasilık & 672 & 2,97 & 1,453 \\
\hline & Etki & 672 & 3,86 & 1,179 \\
\hline & Risk Puanı & 672 & 16,18 & 6,896 \\
\hline \multirow{3}{*}{$\begin{array}{l}\text { Okulda verilen öğrenci yemeklerinin denetimlerinin } \\
\text { yapılmaması }\end{array}$} & Olasilık & 672 & 2,69 & 837 \\
\hline & Etki & 672 & 4,66 & ,574 \\
\hline & Risk Puanı & 672 & 19,39 & 3,320 \\
\hline \multirow{3}{*}{$\begin{array}{l}\text { Okulun temizlik, ısınma ve benzeri alanlarında } \\
\text { öğrencilerin çalıştırılması }\end{array}$} & Olasılık & 672 & 2,29 & 1,031 \\
\hline & Etki & 672 & 2,30 & ,990 \\
\hline & Risk Puanı & 672 & 7,90 & 5,301 \\
\hline \multirow{3}{*}{$\begin{array}{l}\text { Okul binası ve eklentilerinin sabotaj, yangın, hırsızlık ve } \\
\text { diğer tehlikelere karşı gerekli koruyucu güvenlik tedbirlerin } \\
\text { alınmaması }\end{array}$} & Olasilık & 672 & 2,98 & 1,464 \\
\hline & Etki & 672 & 4,20 & 876 \\
\hline & Risk Puanı & 672 & 17,68 & 5,829 \\
\hline \multirow{3}{*}{ Toplam } & Olasılık & 672 & 2,96 & ,685 \\
\hline & Etki & 672 & 4,05 & ,393 \\
\hline & Risk Puanı & 672 & 17,19 & 2,671 \\
\hline
\end{tabular}


Tablo 7 incelendiğinde; Güvenlik ve Sağlık faktörü altındaki 39 numaralı “Okulda ve yakın çevresinde kırık pencere ve kapı, korkuluksuz balkon ve merdiven, kapısız asansör boşluğu, fosseptik çukur ve benzeri tehlikelerin olması" riskinin, 43 numaralı "Okulda ve pansiyonlarda öğrencilerin istismara uğramamaları yönünde gerekli önlemlerinin alınmaması" riskinin ve 45 numaralı "Okulda verilen öğrenci yemeklerinin denetimlerinin yapılmaması" riskinin puanının yüksek (19 puan üzerinde) olduğu, 38 numaralı "Öğrenci oyun alanlarındaki oyun araçlarının (kale, pota, kaydırak vs.) düzenli bakımlarının yapılmaması" riskinin, 40 numaralı "Okulun ssıtma ve soğutma sistemlerinin sağlıklı çalışmaması" riskinin, 41 numaralı "Okuldaki elektrik ve doğalgaz tesisatlarının bakım-onarımlarının düzenli yapılmaması" riskinin, 42 numaralı "Acil durum eylem planları hazırlanarak doğal afet tatbikatlarının belirli periyotlarla yapılmaması" riskinin, $44 \mathrm{nu}-$ maralı "Okul dışı mekânlara yapılan gezilerde gerekli önlemlerin alınmaması" riskinin ve 47 numaralı "Okul binası ve eklentilerinin sabotaj, yangın, hırsızlık ve diğer tehlikelere karşı gerekli koruyucu güvenlik tedbirlerin alınmaması" riskinin puanının yüksek orta riskli alanda (16-19 puan arası), diğer 46 numaralı "Okulun temizlik, 1sınma ve benzeri alanlarında öğrencilerin çalıştırılması" riskinin ise düşük riskli alanda (9 puan altı) yer aldığı görülmektedir.

Yüksek riskli olan maddeler arasında 43 numaralı “Okulda ve pansiyonlarda öğrencilerin istismara uğramamaları yönünde gerekli önlemlerinin alınmaması" riskinin (etki: 4,77 - olasılık: 2,52) ve 45 numaralı "Okulda verilen öğrenci yemeklerinin denetimlerinin yapılmaması" riskinin (etki: 4,66 olasılık: 2,69) etki puanı ile olasılık puanı arasındaki puan farkının fazla (ikiye yakın) olduğu, yüksek puanlı diğer 39 numaralı "Okulda ve yakın çevresinde kırık pencere ve kapı, korkuluksuz balkon ve merdiven, kapısız asansör boşluğu, fosseptik çukur ve benzeri tehlikelerin olması" riskinin (etki: 4,58 - olasılık: 4,43) ise etki ve olasılık puanlarının birbirine yakın ve 1 puandan az fark olduğu görülmektedir.

Orta riskli olan maddeler arasında ise 41 numaralı "Okuldaki elektrik ve doğalgaz tesisatlarının bakım-onarımlarının düzenli yapılmaması" riskinin (etki: 4,15; olasılık: 2,50), 42 numaralı "Acil durum eylem planları hazırlanarak doğal afet tatbikatlarının belirli periyotlarla yapılmaması" riskinin (etki: 4,38; olasılık: 2,70) ve 47 numaralı "Okul binası ve eklentilerinin sabotaj, yangın, hırsızlık ve diğer tehlikelere karşı gerekli koruyucu güvenlik tedbir- 
lerin alınmaması" riskinin (etki: 4,20; olasılık: 2,98) etki puanı ile olasılık puanı arasındaki puan farkının 1'den fazla olduğu, diğer orta risk puanına sahip; 38 numaralı "Öğrenci oyun alanlarındaki oyun araçlarının (kale, pota, kaydırak vs.) düzenli bakımlarının yapılmaması" riskinin (etki: 3,85- olasılık: 3,54), 40 numaralı "Okulun ısıtma ve soğutma sistemlerinin sağlıklı çalışmaması" riskinin (etki: 3,82; olasılık: 3,02) ve 44 numaralı "Okul dışı mekânlara yapılan gezilerde gerekli önlemlerin alınmaması" riskinin (etki: 3,86- olasılık: 2,97) etki ve olasılık puanlarının birbirine yakın ve 1 puandan az olduğu görülmektedir. Bu kategorideki tüm risklerin etki puanlarının olasılık puanlarından yüksek olduğu görülmektedir.

\section{Tartışma ve Sonuç}

Araştırma kapsamında okullarda oluşabilecek riskli alanlara ilişkin yapılan değerlendirmelerin geneline ve alt boyutlarına ait bulgular incelendiğinde, tüm faktörlerin ve ölçeğin genel risk puanları ortalamalarının orta riskli alanda yer aldığı, risk puan ortalaması en yüksek olan faktör ise "Mesleki Gelişim ve Etik (Öğretmen)" faktörü olduğu görülmektedir. Buradan hareketle, öğretmenlerin mesleki gelişimlerine verdikleri önem ve etik ilkelere riayet hususunda sorunlar olduğu ve bunun sonucunda oluşabilecek durumların nispeten daha büyük risk oluşturduğu söylenebilir.

Genel anlamda bir toplumun ya da toplum içerisindeki grupların farklı etkiler neticesinde oluşan davranış normları şeklinde tanımlanan etik ile ilgili ilkelerin evrensel olduğu ve farklı bölgelerde fazla değişim göstermediği söylenebilir. Mesleki alanlarda genel kabul görmüş ortak etik ilkeleri bulunmakla birlikte her alanın kendine özgü ilkeleri de mevcuttur (Gözütok, 1999). Nitekim her meslekte olduğu gibi öğretmenlik mesleğinin de kendine özgü etik ilkeleri bulunmaktadır. Bu kapsamda Milli Eğitim Bakanlığı ekonomik ve sosyal hayatı olumsuz etkileyen, ahlaki değerleri aşındıran, kamu kurumlarına olan güveni zedeleyen tutum ve davranışlara karşı eğitim-öğretim çalışanları için mesleki etik ilkeleri hazırladığını duyurmuştur (MEB, 2015).

Okullarda öğrencilerine her yönden rol model olan öğretmenlerin etik ilkelere uygun davranma hususunda diğer mesleklere göre daha fazla dikkat etmeleri gerekmektedir. Çünkü öğretmenler bu ilkelere uyarak eğitimöğretim süreçlerinde verilen bilgilerin pekiştirilmesini ve özümsenmesini 
sağlayarak ilerde farklı meslekleri seçecek ve toplumun farklı kademelerinde yaşam sürecek olan öğrencilerine etik davranışlar kazandırma yönünde örnek olmaktadırlar.

Etki ve olasılık puan ortalamaları arasındaki farkın en yüksek olduğu $(1,09)$ faktör "Güvenlik ve Sağlık", puan ortalamaları arasındaki farkın en düşük olduğu $(0,4)$ faktör ise "Liderlik-İletişim (Yönetici)" faktörüdür. Bu sonuçlara göre okullarda güvenlik alanlarında meydana gelebilecek risklerin oluşma olasılığının düşük olarak puanlanmasına rağmen oluştuğu takdirde etkisinin yüksek olacağı şeklinde bir değerlendirme yapıldığı anlaşımaktadır.

Tüm faktörlerde ve ölçeğin genelinde olasılık puan ortalamalarının etki puan ortalamalarından düşük olduğu görülmektedir. Bu sonuç eğitim kurumlarında oluşabilecek risklerin oluşma ihtimalinin düşük olduğu fakat oluştuğu takdirde ciddi etkiler oluşturabileceği şeklinde yorumlanabilir.

Binkhorst ve Kingma'nın (2012) yaptığı araştırmada okullarda çok farklı türde risk unsurunun bulunduğunu, bu risklere okulun farklı paydaşlarının farklı önemler atadıklarını ve her risk unsurunun farklı algılanabildiğini vurgulamışlardır. Burada belirtilen risk objeleri ve bunlara atanan önem derecelerinin incelendiği araştırmada okulun güvenlik alanındaki risklerin belirsizlikler oluşturduğu ve çoğu paydaşın da bunlardan haberinin olduğu, bununla birlikte paydaşların tüm riskleri eşit seviyede ciddiye almadıkları ve bunlarm hepsini güvenlik yönetim yönetmeliğine koymak istedikleri belirtilmektedir. Ortaya çıkan bu sonuçlara göre risk objelerinin tanımlanmasında sübjektif unsurların söz konusu olabileceği anlaşılmaktadır.

Okul yöneticileri ve öğretmenlerin "Yasallık ve Etik (Yönetici)" faktörü kapsamındaki risklerden; denetim görevlerinin aksatılmasını, kurumun hedeflerine ulaşmasını engelleyecek risklere karşı önlem alınmamasını ve kurallara uymayan öğrenciler için disiplin hükümlerinin uygulanmamasına daha fazla önem verdikleri görülürken, okulda tutulması gereken belge, defter, çizelge ve formların doğru şekilde tutulmamasına ve seminer çalışmalarını planlama ve takibinin yapılmamasına daha az önem verdikleri anlaşılmaktadır.

Hem kamu hem de özel sektör için yönetimin en temel ögelerinden biri olan denetim ve değerlendirme Ertekin'e (2004: 57) göre örgütün gerçekleştirdiği iş başarımıyla (performans), önceden yapılmış olan plan-programa göre gerçekleşmesi istenen sonuçlar arasındaki farklılıkları tespit etmek ve 
bu ilişkiler arasındaki uygunluğun sağlanması için yapılacak olan her türlü yönetimsel eylemler dizisidir. Belli amaçları gerçekleştirmek ve varlıklarını sürdürmek isteyen örgütler için yönetim basamaklarının sonuncusu ve vazgeçilmezi olan denetim ve değerlendirme yönetimsel bir ihtiyaç ve zorunluluktur. Nitekim Demirtaş ve Akarsu'ya $(2016$, s.3) göre örgütler amaçlarını gerçekleştirmede etkili oldukları sürece varlıklarını sürdürebilirler. Örgütlerin etkili ve yeterli olabildiğini tespit etmek için de denetim-teftiş süreci olmazsa olmaz bir aşamadır.

Başar'a (2000) göre eğitim kurumlarında yapılacak denetim; nitelik, eşitlik, verimlilik, okullaşma, maliyet, finansman ve yönetim konularında iyileştirmenin sağlanabilmesi için sınırların belirlenmesinde, önceliklerin tespitinde ve stratejilerin oluşturulmasında yardımcı olmayı amaçlamaktadır. Okullarda denetimin gerekliliğini ve önemini vurgulayan Kiniş (1988) ise denetim mekanizmasının ekonomik, toplumsal ve eğitimsel alanlarda başboşluğu ortadan kaldıran önemli bir işlev olduğunu, nüfus artışına paralel olarak artan okulların denetimsiz, plansız ve programsız olarak varlıklarını sürdürmelerinin kent yaşamına kaotik bir hava getireceğini ileri sürmektedir.

Okullarda öğretmenlerin ders ve performans denetimi görevi önceleri müfettişlerdeyken, 2014 yılından sonra bu görevlerin de okul müdürlerine verilmesi nedeniyle yönetim için önemi vurgulanan denetim görevi hususunda okul yöneticilerinin hassas davranmaları gerekmektedir. Zira Wiles ve Bondi'ye (1996, s.9) göre denetim, bir insan ilişkileri sürecidir ve denetçi, insanların birbirini dinlemesini sağlayarak iletişim kuran, benzer sorunları ve birbirine yardımı olabilecek kaynakları bir araya getiren, kişileri yeniliklere teşvik eden ve insanların sorunlarına çözüm bulmaları için yönlendiren kişidir (Akt; Aydın, 2013, s.5)

Okulun tüm kaynaklarını (insan, madde vb.) etkin bir şekilde kullanarak, okulu amaçlarına ulaştırmakla görevli olan okul yöneticileri denetim sayesinde eğitim sistemindeki mevcut uygulamalar arasında karşılaştırma yaparak, örgütsel faaliyetlerin benimsenen amaçlar doğrultusunda, saptanan ilkelere ve kurallara uygun olup olmadığını, örgütün amaçlarına ulaşma derecesini ve sapmaları tespit ederek, bu sapmaların nedenlerini ortaya koyar ve giderilmesi için yöntemler geliştirir (Aydın, 1993; Başaran, 2000; Bursalığlu, 2003; Demirtaş ve Akarsu, 2016). Burada okul yöneticilerinin denetim ve rehberlik görevlerini okulun amaçlarını gerçekleştirecek şekilde 
yürütebilmeleri için denetim yapilan alanlarda denetledikleri personelden daha fazla bilgi ve deneyim sahibi olmaları gerektiğinin de bilinmesi gerekir. Aksi takdirde bu rehberlik ve denetim faaliyetlerinin pek bir faydası olmayacağı gibi denetlenen kişileri olumsuz etkileyerek çalışma isteklerini düşürebilecektir.

Katılımcılara göre kurumun hedeflerine ulaşmasını engelleyecek risklere karşı önlem alınmamasının önemli bir risk olduğu ortaya çıkmıştır. Okulda oluşturulan iç kontrol sistemi ile risklerin yönetilmesinin amacı, bu risklerin krize dönüşmesini engellemektir. Aksi takdirde risk yönetimi aşamasından daha zorlu ve yıpratıcı olan kriz yönetimi aşamasına geçilmek zorunda kalınacaktır. Peker ve Aytürk'e (2000, s.386) göre yöneticilerin liderlik bilgi, beceri ve deneyimlerine en çok krizle karşılaşıldığında ve krizin yönetiminde gereksinim duyulur. Çünkü yöneticilerin en önemli görev ve sorumluluklarından biri örgütte krizler için önlem almak ve oluştuğunda başarılı bir şekilde üstesinden gelmektir. Bu bakımdan yöneticilik bir anlamda sorun çözme sürecidir denebilir.

Okullarda risk olarak görülen bir diğer husus disiplin sorunlarıdır ve bu sorunlar şüphesiz tüm okulların ortak sorunudur. Son yıllarda okullarda sürekli artış gösteren şiddet ve disiplin sorunlarının okul yöneticileri tarafından öncelikli olarak önlenmesi gerekmektedir. Literatürde bu konu ile ilgili yapılmış çalışmaların hemen hepsinde okullardaki disiplin hükümlerinin uygulanabilir olması ve disiplin kuralların uygulayıcıların arasında tutarlılığın olması hususu önemle vurgulanmaktadır. Örneğin Bakioğlu ve Tokmak'ın (2009) okullarda oluşturulması gereken disiplin anlayışları konusunda yapmış oldukları araştırmada, öğretmenlerin tamamına yakını kişiler arasında disiplin anlayışında farklılıklar olduğu konusunda görüş bildirmiştir. Öğretmenler disiplin anlayışlarının oluşmasında kendi kişisel değer yargılarının etkisinin ön planda olduğunu ve disiplini kendi öncelikli değerlerine göre tanımlamaktadırlar. Araştırmada; öğretmenlere göre cinsiyet, yaş, branş, görev, yetişme tarzı, alınan eğitim türü, hayata bakış açısı ve kişisel değer yargıları gibi unsurlar disiplin farklılıkların nedenlerindendir. Bunların arasında hayata bakış açısı, yetişme tarzı ve kişisel değer yargılarındaki farklılık gibi unsurlar diğer unsurlara göre daha fazla vurgulanmıştir.

Okulda eğitimsel lider olarak okul yöneticileri de, okulun bulunduğu çevre, oluşturulan örgüt kültürü ve değerlerle çelişmeyecek şekilde okulda 
disiplini sağlamak için çaba sarf etmelidirler. Bu disiplinin oluşturulmasında mutlak doğru bir yöntem bulunmamakla beraber her okulun kendine özgü dinamikleri ve genel kabul görmüss ilkeler gözetilerek okul için en uygun yaklaşım benimsenmelidir. Bu noktada katılımcların riskli olarak gördükleri disiplin hükümlerinin uygulanmaması kadar bu kuralların aşırı uygulanmasının da farklı risklere kapı aralayacağını belirtmek gerekir. Bu ikisi arasındaki dengenin sağlanması da yine okul yöneticilerinin uzmanllğına kalmaktadır.

Okul yöneticileri ve öğretmenlerin "Liderlik - İletişim (Yönetici)" faktörü kapsamındaki risklerden; çalışanlar arasında ideolojik, siyasal ve sendikal gruplaşmalara engel olunmamasını nispeten daha önemli gördükleri, çalışanların mesleki ve kişisel gelişim faaliyetlerine katılmaları yönünde teşvik edilmemelerini ise diğer risklere göre daha az önemli gördükleri söylenebilir.

İlgili literatür ve güncel anlayış kurumun insan kaynağının sistematik ve bilimsel yöntemler kullanılarak iyi bir yönetim sergilenmesinin, verimliliğin artırılmasında en önemli unsurlar olduğuna işaret etmektedir. Bu bağlamda personel mekanik bir varlık gibi görülerek sadece ücretlendirme yöntemine göre motivasyon sağlanacağı varsayımına dayanan insan kaynakları politikaları yerine, güdülenmenin karmaşık ve farklı sebeplerini ortaya çıkarmaya yönelik modern, bilimsel yöntemlerle kurumsal verimlilik artırılmaya çalışılmalıdır. $\mathrm{Bu}$ açıdan insan kaynakları politikalarını; çalışanların işe alınmaları, kuruma uyum sağlama süreçleri, eğitimleri, performanslarının değerlendirilmesi, kariyer planları, teşvik ve disipline edilmeleri gibi politika ve prosedürler oluşturur (GAO, 2001, s.15).

Milli Eğitim Bakanlığında insan kaynakları politikalarını oluşturma görevi üst yöneticilerdedir. Yönetim politika oluştururken hukuka ve yasalara uygun, şeffaf ve hesap verilebilir bir anlayışla bu politikaları oluşturmalıdır. İnsan kaynakları uygulamalarında ise tüm yönetim kademeleri ile beraber çalışanların tamamının sorumluluğu bulunmaktadır. Göreve yeni başlayan personelin işe uyumu, eğitilmesi, iş arkadaşlarının performanslarının iyileştirilmesi, görevin işbirliği içinde yapılması, moral ve motivasyonu yükseltecek pozitif ilişkilerin geliştirilmesi, görev esnasında sağlık ve güvenlik önlemlerine dikkat edilmesi, çalışanların istek ve şikâyetlerinin dikkate alınması vb. bu sorumluluklara örnek olarak verilebilir. Eğitim çalışanları diğer görev ve sorumluluklarının yanında bu unsurları da ihmal etmemelidirler. 
Erdoğan’a (2003, s.141) göre okulda görev yapan kişilerin değer yargılarının ve hayat tarzlarının farklı olması, düşünce ve davranışların farklı ölçütlere göre değerlendirilmesi, gruplar arasında yaşanan iletişim problemleri, karşılıklı beklentilerindeki uyuşmazlık, manevî değer, ideoloji ve inanç farklılıkları gibi unsurlara bağlı olarak kişisel değer yargılarının farklılaşmaSı ve çatışmaların yaşanması kaçınılmazdır. Okuldaki insani ilişkiler ve yaşanan çatı̧maların düzeyi öğretmen ve yöneticilerin motivasyonunu artırdığı ya da azalttığ1 için okuldaki eğitim sürecine etki etmektedir. Bakioğlu ve Tokmak'a (2009) göre ilişkiler açısından öncelikli değerler değişse de dürüstlük, samimiyet, sevgi, saygı, paylaşım, hoşgörü, güven ve eşitlik gibi değerler öğretmenler için daha öncelikli değerlerdir. İlişkilerde problem olmaması için bu değerlerin yalnızca önemseniyor ve isteniyor olduğunu dillendirmek değil, aynı zamanda özümsemek, içselleştirmek ve davranışlara yansitmak gerekmektedir.

Öte yandan Türkiye'de yapılan araştırmalara göre eğitim çalışanları okullarda oluşan ayrışmaların en büyük nedenlerinden biri olarak eğitim alanında faaliyet gösteren sendikaları göstermektedirler. Örneğin Kara (2016) ile Berkant ve Gül (2017) tarafından yapılan araştırmalarda öğretmenlere göre sendika üyesi olmak ötekileştirmeye yol açmakta ve öğretmenler arasında ayrışmalara neden olabilmektedir. Söz konusu ötekileştirmenin özellikle kadrolaşma, ideolojik kutuplaşma, yalnızlaştırma, ayrı̧̧ırma ve mahalle baskısı gibi yollarla yaşatıldığı vurgulanmaktadır. Bunların yanında katılımcıların çoğunluğu eğitim sendikalarının siyasallaşmaması gerektiğini düşünmektedirler. Siyasileşerek bölünmek yerine birlikte hareket edip ekonomik, sosyal, özlük hakları ve özgürlük gibi alanlarda üyelerin çıarlarının sağlanması daha akılcıdır.

Tüm bunlardan yola çıkarak çatışmalara ve ayrışmalara sebebiyet verecek siyaset, ideolojik propagandalar ve benzeri faaliyetlerin okula girmemesi gerektiği sonucuna ulaşılmaktadır. Bunun için de siyasi ve ideolojik bakış açısı ne olursa olsun okulda ortak değerler benimsenerek, tüm çalışanların karşılıklı anlayışa dayalı bir kurum kültürünü özümsemiş olmaları gerekmektedir.

Katılımcıların "Sınıf Yönetimi ve Öğretim Süreci (Öğretmen)" faktörü kapsamındaki risklerden öğrencilerin öğrenme özellikleri ve ders seviyelerinin doğru belirlenmemesi riskini önemli gördükleri, öğretmenlerin derslerde sesini, jest ve mimiklerini ve beden dilini gerektiğinden fazla ya da az 
kullanması riskine ise diğer risklere oranla daha az önem verdikleri görülmektedir.

Türk Eğitim Derneğinin (TED, 2009) öğretmen yeterlikleri konulu raporunda, öğretmenlik mesleği genel yeterliklerinin, tüm alanlarda bir yeterlik sorunu olduğu ve geliştirilmeye ihtiyaç olduğu açıklanmıştır. Şahin ve Ersoy (2010) tarafından yapılan çalışmada ise öğretmenlerin ölçmedeğerlendirme konularında hizmet içi eğitim ihtiyaçlarının bulunduğu ve öğretmenlerin kendilerine yardımcı olabilecek yeterli sayıda ölçme değerlendirme alanı uzmanının olmadığı görüşünde oldukları vurgulanmıştır.

Keçici ve Ektem'e $(2017$, s.10) göre okullarda yapılan değerlendirme faaliyeti gibi ölçme de öğretmenler için özel bir yetenektir ve öğrenci seviyelerinin ölçülmesi ve değerlendirilmesi her duruma özel bir kıstas uygulanarak yapılmalıdır. Ölçme kıstasları, öğrencilerin performanslarının değerlendirilebilmesi için gereklidir ve aynı zamanda öğrencilere verilecek ödev ve görevlerin ağılık ve dağılımını belirlemektedir. Ölçme ayrıca öğrencilerin yeteneklerinin senkronize edilmesi sürecinde ve öğretimin planlanması esnasında en uygun öğretim yapısının oluşturulması için ihtiyaç duyulan öğretimsel bir gerekliliktir. Bu bakımdan öğretmenler eğitim öğretimde yeni yöntemler geliştirme ve alternatifler oluşturmanın yanı sıra ölçme ve değerlendirme faaliyetlerini de doğru bir şekilde gerçekleştirmelidirler Dönem başında o dönemde işlenecek derslerin hangi kaynaklardan ve nasıl işleneceği, yapılacak olan ölçme ve değerlendirmenin ne şekilde yapılacağı öğretmenler tarafından açık bir şekilde ortaya konulması gerekmektedir. Ayr1ca öğretmenler; öğretim materyallerini ve içeriğini, sınıf düzenini ve ölçmedeğerlendirme süreçlerini öğrencilerin seviyelerini dikkate alarak tasarlamalıdırlar (Şahin ve Yıldırım, 2010).

Öğretmenlik mesleği sözlü ve sözlü olmayan iletişim becerilerinin etkili bir şekilde kullanımını gerektiren bir nitelik taşıması nedeniyle beden dilinin etkin kullanılması, bir iletişim süreci olan eğitim-öğretimin başarılı bir şekilde sonuçlandırılması bakımından önem arz etmektedir. Yapılan bazı araştırmalarda öğretmenlerin sınıf içinde mimikleri, imleri, jestleri ve beden dilini yeterince kullanmadıkları ve iletişim becerileri yönünden yetersiz oldukları sonucuna ulaşılmıştır (Dağlı ve Öner, 2002, s.28). Öğretmenlerin öğrencilerle olan iletişimi, eğitim-öğretim süreçlerindeki bilgi aktarım seviyesi ve öğrencilerin davranışsal gelişimi açısından önemlidir. Bu bakımdan öğrenmenin gerçekleşmesi ve davranışların kazanılması sürecinde öğret- 
menler, sözel iletişimin yanı sıra beden dillerini de kullanmalıdırlar. Çünkü sınıf içi iletişimde öğretmenin bakışları ve duruşu, jest ve mimikleri, olaylara karşı sergilediği tutum ve davranışları öğrenciler tarafından önemsenmektedir.

Bu araştırmada da öğretmenlerin derslerde sesini, jest ve mimiklerini ve beden dilini gerektiğinden fazla ya da az kullanması hususu riskli bulunmuş ancak diğer risklere göre etki ve önem düzeyi düşük olduğu şeklinde değerlendirilmiştir. Çalışkan ve Yeşil'e (2005) göre bu riskli durumun ortadan kaldırılması için öğretmenler vücutları vasıtasıyla konumlarını öğrencilerine hissettirebilmeli aynı zamanda çevresi ile de etkileşim sağlayacak sözsüz iletişim kanallarını kullanmalıdırlar. Ayaktayken, otururken ve yürürken kendini bırakmış ve bitkinlik imajları sergilememelidir. Alkan'a (2000, s.14) göre ise öğretmenlik mesleği bir denge mesleğidir ve öğretmenler yalnızca bilgi aktaran bireyler olarak düşünülmemelidir. Benzer araştırmalarda da belirtildiği üzere öğretmenlerin performansları ve taşıdıkları sorumluluk, öğrencilerin gelecek yaşamlarında belirleyici unsurlardan olacağı için karakteri ve kişilik özellikleri sağlıklı olmayan, iletişim becerileri yetersiz, sportif, sanatsal ve kültürel faaliyetlerden uzak, bilimsel çalışma mantığını benimsememiş, psikolojik olarak sorunlu kişiler öğretmenlik mesleğini icra etmemelidirler.

Okul yöneticileri ve öğretmenlerin “Mesleki Gelişim ve Etik (Öğretmen)" faktörü kapsammndaki, kişisel-psikolojik sorunları olan öğretmenlerin yaşadıkları sorunları sınıfa yansıtmaları riskini önemli gördükleri, öğretmenlerin alanlarıyla ilgili yayımlanan yazıları takip etmemelerine ise diğer risklere oranla daha az önem verdikleri söylenebilir.

İhtiyaçları ve öğrenme biçimleri farklı olan tüm öğrencilerin öğrenme faaliyetlerinden sorumlu olan eğitimcilerin tecrübe kazanmaları, zaman alıcı ve önemli bir süreçtir. Bu nedenle eğitimcilere gerekli olan teorik bilgiler ve pratik uygulamalar bir bütün olarak sabırla verilmelidir. Burç’a (2006) göre de okulun başarısı eğitimcilerin öğretici ve yönetici bilgisine ve bakış açısına sahip olmalarından geçmektedir. Alanlarında yetkin olan eğitimciler öz denetim özellikleri sayesinde karşılarına çıkan sıkıntılı durumların üstesinden gelebilme yeteneğine sahiptirler ve her türlü dış dayatmaya karşı dirençli davranabilmektedirler. Benzer şekilde Kutlu'nun (2006) çalışmasında ise, eğitimcilerin bulundukları ortamlarda eğitim lideri olarak grup dinamizmini artırmaları gerektiği, yönetim ile öğretimi kenetli hale getirmek için 
gayret göstermeleri gerektiği ve çevresel faktörlerin doğru analiz edilmesi için donanımlı olmaları gerektiği vurgulanmaktadır. Buradan yola çıarak öğretmenlerin sadece kendilerinden sorumlu değil, aynı zamanda öğrencilerine ve çevrelerine karşı da örnek olmaları ve diğer meslek gruplarına göre psikolojik olarak daha güçlü olmaları gerektiği sonucuna ulaşmaktayız. Bunun için öğretmenlerin hayat boyu gelişim felsefesini benimseyerek buna göre hareket etmeleri, psikolojilerini daha güçlü hale getirecektir. Zira yapılan araştırmalar da bu görüşü desteklemektedir. Bandura'ya (1993, 1997; akt. Çolak, Yorulmaz ve Altınkurt, 2017, s.21) göre öğretmenlerin yetenekleri ve özyeterlik inançları, öğrencilerin bilişsel ve akademik yeterliklerini sağlayacak öğrenme ortamlarının oluşumunda etkilidir. Yani öğretmenlerin öğretimsel yeterliklerine olan inanç düzeyleri, sınıfta gerçekleştirilen faaliyetlerin şekillenmesinde en belirleyici etkenlerdendir.

Erol'a (2006) göre okullarda etkili bir öğrenme ortamının oluşturulabilmesi için akılcı bir mevzuatla, rasyonel bireyler yetiştirme hedefine kilitlenmiş, maksimum verimlilik için gayret eden sağlıklı bir örgüt yapısının gerekli olduğu savunulmaktadır. Öğretmenlerin psikolojik sermaye düzeylerini belirlemek amaciyla Kaya, Balay ve Demirci (2014) tarafindan yapılan bir araştırmada ise lisansüstü eğitim yapmış öğretmenlerin psikolojik sermaye düzeylerinin, ön lisans ve lisans mezuniyet derecesine sahip olan öğretmenlere göre anlamlı şekilde daha yüksek olduğu ve aylık üç-beş kitap okuyan öğretmenlerin psikolojik sermaye düzeylerinin, aylık bir-iki kitap okuyan veya hiç kitap okumayanlara göre anlamlı şekilde daha yüksek olduğu vurgulanmaktadır.

Diğer meslekleri icra eden kişiler gibi öğretmenler de hayatın bazı dönemlerinde ekonomik ya da ailevi sıkıntılar, depresyon, bunalım ve benzeri psikolojik sorunlar yaşayabilirler. Yaşanan bu sıkıntıların çok farklı nedenleri olabilir fakat bu sorunların üstesinden gelmek için kişinin bu durumdan kurtulma yönünde çaba sarf etmesi gerekmektedir. Gerek özel yaşamındaki kişilerin gerekse iş arkadaşlarının bu süreçte destek olmaları önemlidir. Hal böyleyken fiilen derse giren eğitimcilerin söz konusu sıkıntılarının süreklilik göstermesi ve okul ya da sınıf ortamına yansıması, öğrencilerin ve iş arkadaşlarının yaşamlarında olumsuz etkilere sebep olabilecek önemli bir risk olarak görülmektedir. Bu riske bağlı olumsuzlukların gerçekleşmemesi için de yetkililer tarafından gereken tedbirlerin zamanında alınması gerekir. 
Okul yöneticileri ve öğretmenler "Güvenlik ve Sağllk" faktörü kapsamındaki risklerden, okulda ve yakın çevresinde kırık pencere ve kapı, korkuluksuz balkon ve merdiven, kapısız asansör boşluğu, fosseptik çukur ve benzeri tehlikelerin olması riskini önemli görmektedirler. Okulun temizlik, ısınma ve benzeri alanlarında öğrencilerin çalıştırılması riskini ise diğer risklere oranla daha az önemli görmektedirler.

Öğrencilerin, diğer öğrencilerden veya çevreden gelebilecek şiddet, saldırganlık, taciz, alkol, uyuşturucu gibi istenmeyen durumlardan korunmaları; trafik kazaları, yangın, sel ve deprem gibi doğal afetlere karşı da gereken tedbirler alınarak can güvenliğinin sağlanması, başta okul yöneticileri olmak üzere tüm eğitim çalışanlarının en önemli görevlerindendir (Boztuğ ve Akyol, 2017). Okulda düzenin sağlanması asayiş açısından, fiziksel çevre açısından ve gıda güvenliği açısından önem arz etmektedir. Öğrenciler arasında yaşanan kavgalar, öğrenciler ve öğretmenler arasında yaşanan şiddet olayları, okula yapılan dış müdahale ve baskınlar, kazalar, intiharlar, hırsızlık vakaları, çeteleşmeler, uyuşturucu madde kullanımı ve satışı gibi okul güvenlik problemlerinin her geçen gün basında daha fazla yer aldığı görülmektedir. Turhan ve Turan'a (2012) göre bu tür istenmeyen olaylar okulun huzurunu ve güven ortamını bozmakta, öğrenci ve öğretmenleri hem fiziksel hem de psikolojik olarak tedirgin etmekte, okula duyulan güveni sarsmakta ve okulda verilen eğitim-öğretim hizmetinin niteliğini düşürmektedir. Hem öğretmenler hem de öğrenciler açısından okulda nitelikli bir öğrenme ortamı oluşturulmasının ön koşulu okulun güvenli bir ortama dönüştürülmesidir. Aksi takdirde öğrenciler ve öğretmenler kendilerini güvende hissedemeyeceklerinden eğitim ve öğretim planlandığı şekilde gerçekleşmeyecektir.

Okul güvenliği ile ilgili yapılan çalışmalarda genel olarak okulların olağanüstü durumlara ve afetlere karşı okulların yeterli hazırlı̆̆ının olmadığı, okullarla ilgili eğitim politikalarının yetersizliği, maddi kaynak sıkıntıları, eğitimsizlik, iletişimsizlik ve medyanın sebep olduğu etkiler ile iç ve diş tehditlerden gelecek güvenlik problemlerine karşı yetersiz kaldıkları (Boztuğ ve Akyol, 2017), yeterli düzeyde temizlik yapılamadığı, giriş-çıkışların kontrolünün sağlanamadığı, sınıf mevcutlarının kapasiteden fazla olduğu, kriz durumlarında ne yapılacağına ilişkin yeterli bilgi ve tecrübeye sahip olunmadığı, okul bahçelerinde ve oyun alanlarında mevcuda göre yeterli alan olmadığı, (Barhan, 2001, s.46), okul güvenlik görevlilerinin güvenliğin 
sağlanmasında yetersiz kaldıkları, okul kantinlerinde denetimlerin yeterli ölçüde yapılmadığı, okul etrafında alkol, sigara gibi zararlı maddelerin satışında yaş sınırı gözetilmediği, okulların fiziki yapılarının ve donanımlarının tehlike oluşturduğu (Turhan ve Turan, 2012), okul ziyaretçilerinin kayıtlarının tutulmadığı, okulların giriş çıkış zamanlarında kargaşaya engel olunamadığı, servis denetimlerinin yeterli yapılmadığı (Öngider, 2013) gibi sorunlar belirtilmektedir.

Yapılan araştırmalarda özetle okulların güvenlikle ilgili çok fazla açığının bulunduğu, psikolojik güvenlik önlemlerinin fiziksel güvenlik önlemleri kadar önemli görüldüğü ayrıca güvenlik açısından okul çevrelerinin de okulun içi kadar önemli görüldüğü belirtilmektedir. Okulların fiziki tasarı$\mathrm{m}$, içinin donanımı ve sosyal ortamı da kişilerin güvenlik algısını doğrudan etkileyen unsurlar olmaları nedeniyle bunlar bir bütün olarak ele alınmalldır. Maslow'un (1970) ihtiyaçlar hiyerarşisinde de belirtildiği üzere güvenlik, çalışma ortamındaki huzur ve rahatlık için en önemli unsurlardandır. Bu nedenle okullarda eğitim öğretimin daha etkili yapılabilmesi için güvenlikle ilgili risklerin kontrol altına alınarak çalışanlara ve öğrencilere rahat bir çalışma ortamı sağlanmalıdır. Ayrıca okulların örgütsel itibar oluşturabilmeleri için de risklere karşı gereken önlemlerin alınması ve güvenliğin sağlanmış olması gerekmektedir.

Sonuç olarak araştırma kapsamında elde edilen okul riskleriyle gerektiği ölçüde mücadele edebilmek için iç kontrol modeline uygun şekilde bir risk havuzu oluşturulması ve oluşturulan bu risk havuzundaki risklerin uygun yöntemlerle sınıflandırılıp, paydaşlar tarafından yapılacak olan değerlendirmelere göre gerekli tedbirlerin alınması, okulların daha etkin ve verimli şekilde yönetilmesine yardımcı olacağı söylenebilir.

\section{Öneriler}

- Tüm kurumlarda olduğu gibi eğitim kurumlarında da stratejik planlama ve iç kontrol sistemi bir bütün olarak tasarlanmalı ve yürütülmelidir. Sistemin bileşenlerinden biri veya bir kaçının eksik olması hedeflere ulaşılmasında engel teşkil edeceğinden, bileşenler bir yapbozun (puzzle) parçaları gibi birbirini tamamlayan unsurlar olarak düşünülmeli ve iç kontrolün tüm standartları eksiksiz şekilde oluşturulmalıdır. 
- İyi bir risk yönetimi, riskler oluştuktan sonra müdahale ederek değil, riskler oluşmadan önlemeye çalışmak ilkesinden hareketle okullarda hızlı ve doğru karar verebilme yetisine sahip okul çalışanlarından kriz ve acil durum ekibi oluşturulmalıdır.

- Okullarda çalışanlara ve öğrencilere riskli durumların tespiti, bildirilmesi ve alınacak önlemlerle ilgili farkındalık eğitimleri verilmelidir.

- Okul rehberlik servislerinin önleyici rehberlik çalışmaları hususunda aktif çalışarak risk altındaki ögrencilerin tespit ve takip işlemlerini aksatmadan yapmalı, her öğrenci ilgi, yetenek ve eğilimine göre kültürel, sosyal ve sportif çalışmalara yönlendirilmelidir.

- Okulların doğal afetler ve olağan üstü durumlara karşı hazır halde bulundurulması için okulda ve civarında bulunan riskli alanlar tespit edilerek bir risk havuzu oluşturulmalı ve bu risklere karşı alınacak önlemler ile ilgili planlar ve tatbikatlar yapılmalıdır.

- Yönetici, öğretmen, öğrenci ve velilerin okullarda oluşabilecek riskli durumların tespiti hususunda sürekli iletişim halinde olmaları sağlanmalıdır.

- Nöbetçi öğretmenlerin oluşabilecek risklere ilişkin görev ve yetkileri net olarak belirtilerek, nöbetler daha etkin hale getirilmelidir.

- Çalışanların özlük haklarının elde edilmesi, korunması ve diğer temel kazanımlar için kurulmuş olan sendikaların üyeleri ve yöneticileri çatışma dili yerine uzlaşı dilini kullanmalı, öğretmenlerin motivasyonlarını olumlu yönde etkileceyecek faaliyetler yürütmeli ve okullarda riskli alanların azaltılması için katkı sağlamalıdırlar.

Eğitim kurumlarında oluşabilecek risklerin tespiti ve değerlendirilmesi hususunda nicel ve nitel araştırmalar ile çalışma grubu farklı kademe eğitim yöneticilerinin, öğretmenlerin, velilerin ve öğrencilerin görüşlerine göre çeşitlendirilip, genişletilerek başka yöntemler ve başka ölçekler kullanılarak tekrar edilebilir ya da daha detaylı ele alınabilir. 


\title{
EXTENDED ABSTRACT
}

\section{Determination of Strategic Risks in Educational Institutions}

\author{
$*$ \\ Ömer Faruk Ak - Sevilay Şahin \\ Governorship of Niğde, Gaziantep University
}

Disruptions in educational institutions can lead to serious loss of rights and at the same time create irreparable damages for the future of the country. Therefore, there is no room for the schools to operate on a contingency basis and all activities must be carried out according to the plan. Accordingly, strategic plans have been made for the future at certain periods for nearly a decade in order to advance towards the goals of schools and prevent the loss of rights of the students who receive education.

It is known that there are some problems with the implementation of the strategic plans, which are expected to have many theoretical benefits in schools. It is difficult to say that strategic planning, which is required to be prepared and implemented in the schools according to the legislation has been prepared functionally and the implementation processes are carried out according to the purpose.

It can be said that the main shortcoming of the expected benefit is the lack of implementation of a management model related to how to achieve the goals determined in the strategic plans. Because the success of the strategic planning can be measured by the institution's ability to protect the institution against uncertainty, threats and risks that it may be exposed to, and also to position it correctly by taking advantage of opportunities.

Since the adverse that may occur cannot be completely eliminated, an effective risk management should be implemented in the institution to reduce the risks and minimize the potential adverse effects.

Risk is a phenomenon that is within the structure of the activities and operations of institutions. Risk management, on the other hand, is a discipline that tries to bring it to an acceptable level by reducing the negative effects of uncertainties in the nature of risk. 
The COSO internal control model, which is the most widely adopted and used international risk management model, has been developed with a joint agreement with different professional groups in the U.S. to ensure that institutions can work effectively and efficiently in accordance with the legislation in force and to report the results of all activities in the institution at a reliable level to help the management make the right decisions.

The internal control risk management model, which is also accepted as a risk management model in our country, is expected to gradually make the risks that may arise in both physical spaces and educational processes harmless and increase the probability of reaching the strategic goals determined in the school, and increase the quality and efficiency of education provided in schools that become a safe environment for students. In addition, although schools have similar characteristics in general, this study will provide a guide to the identification of specific risks by taking into account the specific structure of each school and will give a different perspective to school administrators.

In this study, a descriptive method based on the general survey model was used by school administrators and teachers to determine and evaluate the risks that may occur in schools.

The universe of the research is composed of school administrators and teachers from public high schools affiliated with the Ministry of National Education in the city center of Niğde in the 2017-2018 academic year. The research data was collected from 672 people, 74 school administrators and 598 teachers, using the "School Internal Risks Assessment Scale" developed by the researchers and analyzed as necessary.

In this study, the arithmetic average and standard deviation values of the participants' evaluations regarding the risks that may occur in schools are presented in the table.

According to the findings of the research, it is seen that all factors and the general risk score averages of the scale are in the medium-risk area between 15-18 points. The factor with the highest probability score average is Professional Development and Ethics (Teacher), the most effective factor with the highest average is Safety and Health, and the factor with the highest risk score average calculated according to probability and impact scores is the Professional Development and Ethics (Teacher) factor. From this point of view, it can be said that teachers have problems with their professional de- 
velopment and compliance with ethical principles, and that the potential risks are relatively higher.

The most significant difference between impact and probability score averages is "Safety and Health" and the lowest difference between the score averages is the "Leadership-Communication (Manager)" factor. According to these results, although the probability of risks that may arise in security areas in schools is scored as low, it is understood that an assessment is made that the impact will be high, if they occur.

It is seen that the average probability score in all factors and across the scale are lower than the impact score average. This result can be interpreted as the probability of the risks occurring in educational institutions is low, but can have serious effects if they occur.

Risks related to the "Legal and Ethical (Executive)" factor of school administrators and teachers; it is understood that they pay more attention to the failure of audit tasks, not to take precautions against risks that prevent the institution from achieving its goals, and to the failure to implement disciplinary provisions for students who do not comply with the rules, while they are less concerned about not keeping the documents, books, charts and forms that should be journalized at school properly and not planning and monitoring seminar work.

According to the participants, it was revealed that there has been an important risk in not taking precautions against risks that would prevent the institution from achieving its goals. The internal control system established at the school aims to prevent these risks from turning into crisis. Another issue that is seen as a risk in schools is disciplinary issues, and these problems are undoubtedly the common problem of all schools. School administrators must primarily prevent the problems of violence and discipline that have been constantly increasing in schools in recent years.

Risks related to the "Leadership - Communication (Manager)" factor of school administrators and teachers: it can be said that it is relatively important for employees not to interfere with ideological, political and union groupings, and that they consider it less important than other risks to see that employees are not encouraged to participate in professional and personal development activities.

Related literature and current understanding point out that the institution's human resources is the most important factor in increasing efficiency 
by demonstrating good management through systematic and scientific methods. In this context, instead of human resources policies that are based on the assumption that personnel will be motivated only by the way of remuneration, which seems to be a mechanical asset; modern, scientific methods should be used to increase corporate efficiency in order to find out the complex and different reasons of motivation.

It is seen that participants consider the risk of not correctly specified learning characteristics and lesson levels of students among the risks under the "Classroom Management and Teaching Process (Teacher)" factor, and that are less important than in regards to the risk that teachers use their voice, gesture and mimics and body language more or less than necessary.

It can be said that school administrators and teachers consider the risk that teachers with personal-psychological problems under the "Professional Development and Ethics (Teacher)" factor can reflect their problems in the classroom, and that they attach less importance to teachers not following published articles on their fields compared to other risks.

School administrators and teachers consider the risks associated with the "Safety and Health" factor to include broken windows and doors, balconies and stairs without railing, door-free elevator shafts, sanitary pits and other similar dangers at and around school. They consider the risk of employing students in the areas of cleanliness, heating and similar areas of the school are less important than other risks. In summary, it is stated in the researches that schools have too many security gaps, psychological security measures are considered as important as physical security measures, and school environments are considered as important as the school's internals regarding security measures.

The physical design, interior installation and social environment of schools should be treated as a whole as they are factors that directly affect the perception of security. Moreover, the necessary measures should be taken against risks and security should be ensured in order for schools to create institutional reputation.

As a result, it can be said that creating a risk pool in accordance with the internal control model to adequately struggle the school risks obtained as part of the research and classifying the risks in this risk pool with appropriate methods and taking the necessary measures according to the assessments 
made by the stakeholders will help to manage schools more effectively and efficiently.

\section{Kaynakça / References}

Akyüz, Y. (2010). Türk eğitim tarihi MÖ 1000-MS 2010. (18. Baskı). Ankara: Pegem Akademi.

Alkan, C. (2000). Bilimsel, ulusal ve eorensel boyutlu öğretmenlik mesleği, türkiye almanya ve kıbrı' ta öğretmen yetiştirme. Ankara: CBT Yayınları.

Alptürk, E. (2008). Finans, muhasebe ve vergi boyutlarnnda iç denetim rehberi. Ankara: Maliye ve Hukuk Yayınları.

Altınkurt, Y. (2010). Milli Eğitim Müdürlüğü çalışanları ve okul yöneticilerinin stratejik planlamaya ilişkin tutumları. Kuram ve Uygulamada Ĕ̆itim Bilimleri Dergisi, 10 (4), 1927-1968.

Arslan, G. ve Küçüker, E. (2016). Planning activities of school principals and problems encountered in strategic planning. Kastamonu Education Journal, 24(2), 839-856.

Aydın, İ. (2013). Öğretimde denetim (4. Baskı). Ankara: Pegem Akademi Yayınları.

Aydın, M. (1993). Çağdaş eğitim denetimi (3. Baskı). Ankara: Pegem.

Bakioğlu, A. ve Tokmak N. (2009). Öğretmenlerin değer yargilarının eğitim süreçlerine etkisinin incelenmesi. M.Ü. Atatürk Ĕgitim Fakültesi Eğitim Bilimleri Dergisi, 30, 65-83. http://dergipark.gov.tr/download/article-file/1857.

Balcı, A., Çanakçı, H. ve Tan, Ç. (2012). Elazı̆̆ ili, ilköğretim okullarında hazırlanan stratejik planlar ile ilgili okul yöneticisi ve öğretmen görüşleri. Elektronik Sosyal Bilimler Dergisi, 39 (11), 385-394.

Balkar, B. ve Ekici R. (2015). İlkokullardaki stratejik planlama uygulamaları ve örgütsel iletişim arasındaki ilişkinin öğretmen görüşleri doğrultusunda incelenmesi. Turkish Studies -International Periodical for the Languages, Literature and History of Turkish or Turkic, 10(11), 215-234. Ankara. ISSN: 1308-2140

Barhan, A. (2001). İköğretim okullarnnda öğrenci güvenliğinin sağlanması. Yayımlanmamış yüksek lisans tezi. Ankara Üniversitesi Sosyal Bilimler Enstitüsü.

Başar, H. (2000). Ĕ̆itim denetçisi (5. Baskı). Ankara: Pegem A

Başaran, İ.E. (2000). Eğitim yönetimi. Ankara: Kadıŏlu.

Berkant, H. G. ve Gül, M. (2017). Sendika üyesi öğretmenlerin sendikalara yönelik algiları ve sendikalardan beklentileri. İnsan ve Toplum Bilimleri Araştrmalan Dergisi (Journal of the Human and Social Sciences Researches), 6(1), 419-442. ISSN: 2147-1185 
Binkhorst, J. ve Kingma, F. S. (2012). Safety vs.reputation: Risk controversies in emerging policy networks regarding school safety in the netherlands. Journal of Risk Research, 15 (8), 913-935.

Boztuğ Ö. ve Akyol B. (2017). İlkokullarda yönetici ve öğretmen görüşlerine göre okul güvenliği (Aydın İli Efeler İlçesi Örneği). Adnan Menderes Üniversitesi, Sosyal Bilimler Enstitüsü Dergisi, 4(1), 74-95. http://dergipark.gov.tr/download/articlefile/297509

Burç, D. (2006). İköğretim okulu öğretmenlerinin stmf yönetimi yeterlilikleri: Hatay ili örneği. Yayımlanmamış yüksek lisans tezi, Abant İzzet Baysal Üniversitesi Sosyal Bilimler Enstitüsü.

Bursalığlu, Z. (2003). Eğitim yönetiminde teori ve uygulama. Ankara: Pegem A.

COSO. (2004). Enterprise risk management- Integrated framework, application techniques. Commitee of Sponsoring Organizations of the Tradeway Commission. https://www.coso.org adresinden erişilmiştir.

Çalışkan, N. ve Yeşil, R. (2005). Eğitim sürecinde öğretmenin beden dili. Gazi Üniversitesi Kirşehir Ë̆itim Fakültesi Dergisi, 6(1), 199-207.

Çolak, İ., Yorulmaz, Y. İ., ve Altınkurt, Y. (2017). Öğretmen özyeterlik inancı ölçeği geçerlik ve güvenirlik çalışması. Muğla Sttkı Koçman Üniversitesi Ĕ̆itim Fakültesi Dergisi, 4(1), 20-32. Doi: dx.doi.org/10.21666/muefd.319209

Dağll, A. ve Öner M. (2002). İlköğretim okullarının ikinci kademesinde okuyan öğrencilerin fen bilgisi öğretmenlerinin sını içi iletişim davranışlarına ilişkin algılar1. Çă̆daş Ĕ̆itim, 292, 23-30.

Demirtaş, H. ve Akarsu, M. (2016). Öğretmen teftişini müfettiş yerine okul müdürünün yapmasına ilişkin öğretmen görüşleri. İnönü Üniversitesi Eğitim Fakültesi Dergisi, 17(2), 69-93. DOI: 10.17679/iuefd.17251239

Dooris, M. J, Kelley, J. M. ve Trainer, J. F. (2004). Strategic planning in higher education. New Directions for Institutional Research, 123, 5-11.

Erdoğan, İ. (2003). Okul yönetimi öğretim liderliği. Ankara: Sistem Yayıncllk.

Erol, Z. (2006). Simf fögretmenlerinin sinı yönetimi uygulamalarnna ilişkin görü̈sleri. Yüksek lisans tezi, Afyon Kocatepe Üniversitesi Sosyal Bilimler Enstitüsü.

Ertekin, Y. (2004). Çağdaş yönetim ve denetim. Çă̆ Üniversitesi Sosyal Bilimler Dergisi, $1(1)$.

Flkırkoca, M. (2003). Bütünsel risk yönetimi. Ankara: Pozitif Matbaacıllk.

Fraenkel, J. R., Wallen, N. E. ve Hyun, H. H. (2012). How to design and evaluate research in education (8th edition). New York: McGraw-Hill. 
GAO. (2001). Internal control management and evaluation tool. Internal control standards. United States General Accounting Office, August. https://www.gao.gov/assets/80/76615.pdf adresinden erişilmiştir.

Gao, S.S., Sung, M. C. ve Zhang, J. (2013). Risk management capability building in SMES: A social capital perspective. International Small Business Journal. 31(6), 677-700.

Gençkaya, Ö. F. ve Gündoğdu, H. G. (2017). Küresel yönetişim ekseninde stratejik planlarda koordinasyonun önemi. Marmara University Journal of Political Science, 5(Özel Sayl), 125-137. ISSN 2147-6934

Gözütok, F. D. (1999). Öğretmenlerin etik davranışları. Ankara Üniversitesi Eğitim Bilimleri Fakültesi Dergisi, 32(1), 83-99.

Işık, H. ve Aypay A. (2004). Eğitimde stratejik plan geliştirme sürecinde karşlaşılan sorunlar: Çanakkale ilinde yapılan bir inceleme. Gazi Üniversitesi Eğitim Fakültesi Dergisi, 24(3), 349-363.

Kara, M. (2016). Öğretmenlerin Sendikalara üye olmama nedenleri ve sendikalardan beklentileri. Akademik Sosyal Araştrmalar Dergisi (The Journal of Academic Social Science), 4(22), 423-440

Kaya, A., Balay, R. ve Demirci Z. (2014). Ortaöğretimde görev yapan öğretmenlerin psikolojik sermaye düzeylerinin incelenmesi: Şanluurfa İli örneği. Elektronik Sosyal Bilimler Dergisi, 13(48), 47-68. ISSN:1304-0278

Keçici, E. S. ve Ektem, I. S. (2017). Öğretmen eğitiminde uzman görüşüne göre ölçme ve değerlendirmenin genel koşulları. Abant İzzet Baysal Üniversitesi Eğitim Fakültesi Dergisi, 17(3), 1285-1296.

KIDR. (2013). Kamu iç denetim rehberi. Maliye Bakanlığı Bütçe ve Mali Kontrol Genel Müdürlüğ̈̈.

KİKR. (2014). Kamu iç kontrol rehberi. Maliye Bakanlı̆̆ Bütçe ve Mali Kontrol Genel Müdürlügü̈.

Kiniş, S.(1988). Metropoliten yönetimler ve çeore. Yayımlanmamış yüksek lisans tezi, İstanbul Üniversitesi Sosyal Bilimler Enstitüsü.

Kocatepe, Ş. (2010). Eğitimde stratejik planlama ve toplam kalite uygulamalarmin okul yöneticileri tarafindan algilaması. Yayımlanmamıs yüksek lisans tezi, Marmara Üniversitesi Sosyal Bilimler Enstitüsü.

Kriemadis, T. ve Terzoudis C. (2007). Strategic marketing planning in the sport sector. Sport Management International Journal, Scientific Forum in Sport Management, 3(1), 1-19. 
Kutlu, E. (2006). Sinıföğretmenlerinin görüşlerine göre sınf yönetiminde davranış düzenleme sürecinin değerlendirilmesi: Kayseri ili örneği. Yayımlanmamış yüksek lisans tezi, Erciyes Üniversitesi Sosyal Bilimler Enstitüsü.

Küçüker, E. (2010). Türkiye'de eğitim planlaması neyi hedefliyor? International Conference on New Trends in Education and Their Implications, 11-13 November, 153157. ISBN: 9786053641049.

İç denetçilerin çalışma usul ve esasları hakkında yönetmelik (2006). Resmi Gazete (Sayı: 2006/10654).

Maslow, A. H. (1970). Motivation and personality. 2nd. ed., New York, Harper \& Row. ISBN 0-06-041987-3.

MEB. (2015). Genel görüş yönergesi. https://personel.meb.gov.tr/genelge gorus yonerge/etc4b0k20 genelge.pdf adresinden erişilmiştir.

Memduhoğlu, H. B. ve Uçar, İ. H. (2012). Yönetici ve öğretmenlerin stratejik planlama algisı ve okullarda mevcut stratejik planlama uygulamalarının değerlendirilmesi. Mehmet Akif Ersoy Üniversitesi Eğitim Fakültesi Dergisi, 12(23), 234-256

Öngider, N. (2013). Boşanmanın çocuk üzerindeki etkileri. Psikiyatride Güncel Yaklaşımlar, 5(2), 140-161.

Özer, M.A. (2010). Türkiye'de sigorta sektörü ve risk yönetimi. Reasürör, Milli Reasürör A.Ş., 78, 14-32.

Peker, Ö. ve Aytürk, N. (2000). Etkili yönetim becerileri öğrenilebilir ve geliştirilebilir. Ankara: Yargi Yayınevi.

Saltık, N. (2007). İç kontrol standartları. Maliye Bakanlığı Bütçe ve Mali Kontrol Genel Müdürlüğü İç Kontrol Merkezi Uyumlaştırma Dairesi, Ankara. http://kontrol.bumko.gov.tr/Eklenti/6855,saltik-nihal-ic-kontrol-stanadrtlariarastirma-raporu.pdf? Adresinden erişilmiştir.

Steiss, A. W. (2003). Strategic management for public and nonprofit organizations. New York: Marcel Dekker Inc.

Şahin, Ç. ve Ersoy, E. (2010). Sınf öğretmenlerinin ilköğretim 1. kademe fen ve teknoloji dersindeki ölçme-değerlendirmeye ilişkin görüşlerinin değerlendirilmesi. Millî Ĕgitim, 185.

Şahin, S. ve Aslan, N. (2008). İlköğretim okul yöneticilerinin stratejik planlamaya ilişkin görüşleri üzerine nitel bir çalışma (Gaziantep ili örneği). Gaziantep Üniversitesi Sosyal Bilimler Dergisi, 7(1), 172-189.

Şahin, S. ve Yıldırım, S. (2010). Öğrenme tercihleri ve ders algısı. Ahi Evran Üniversitesi Ĕ̆itim Fakültesi Dergisi, 11(3), 153-168.

TDK, (2019). Türkçe sözlük. https://sozluk.gov.tr/?kelime=risk 17.09.2019 
TED, (2009). Türk Ĕgitim Derneği öğretmen yeterlikleri özet rapor. (1. Bask1). Ankara: Adım Okan Matbaacllik

Tunç, İ. (2014). Kurumsal risk yönetim sisteminin stratejik planlamanın başarısı üzerindeki etkisi. Mali Hizmetler Uzmanlı̆̆ Araş̧ırma Raporu, Yalova Üniversitesi Strateji Geliştirme Daire Başkanlığı.

Turhan, M. ve Turan, M. (2012). Ortaöğretim kurumlarında güvenlik. Kuram ve Uygulamada Ĕ̆itim Yönetimi, 1(18), 121-142.

Yelken, Y. T., Kılıç, F. ve Üredi L. (2010). Stratejik planlama uygulamalarına iliş̧in ilk ve orta öğretim okul müdürlerinin görüssleri. Uluslararası Avrasya Sosyal Bilimler Dergisi, 1, 38-50.

Yereli, A. N. (2007) Muhasebe bilgi sistemlerinin risk yönetimine yönelik bir araştırma. Muhasebe ve Denetime Bakış Dergisi, 2, 16-32.

\section{Kaynakça Bilgisi / Citation Information}

Ak, Ö. F. ve Şahin, S. (2021). Eğitim kurumlarında stratejik risklerin tespiti. OPUS-Uluslararası Toplum Araştırmaları Dergisi, 17(34), 9801022. DOI: $10.26466 /$ opus. 814252 